\title{
INTRAPLATE OROGENESIS IN RESPONSE TO GONDWANA ASSEMBLY: KWANGSIAN OROGENY, SOUTH CHINA
}

\author{
YA-JUN XU****, ${ }^{*}$ PETER A. CAWOOD $* * *, \$$, and YUAN-SHENG DU****
}

\begin{abstract}
In intraplate orogens tectonothermal activity occurs at a site removed from a plate margin and is considered to result from localization of far-field plateboundary stresses through a combination of pre-existing structural features and modification of lithospheric properties through fluid alteration, enhanced heat flow and potential thermal blanketing effects. The mid-Paleozoic Kwangsian Orogeny $(460-400 \mathrm{Ma})$ in the South China Craton is geodynamically associated with the far-field response to convergence along the northern margin of east Gondwana. Deformation is focused adjacent to the site of both early Neoproterozoic suturing of the Yangtze and Cathaysia blocks and mid-Neoproterozoic rifting within the craton. Furthermore, this region is one of high crustal heat flow and of widespread fluid release and localized crustal melting during orogenesis. In the late NeoproterozoicCambrian, the South China Craton constituted part of the lithosphere of greater India and was separated from Australia by the Kuunga Ocean. The closure of the Kuunga Ocean during Cambrian-Ordovician time, resulting in final assembly of Gondwana, permitted the stresses sourced from the Terra Australis accretionary orogen in East Gondwana to propagate inboard across the supercontinent. These stresses localized along the site of the Neoproterozoic Nanhua Rift Basin of South China resulting in basin inversion and development of the intraplate Kwangsian Orogeny.
\end{abstract}

Keywords: Intraplate, Kwangsian Orogeny, South China, Kuungan Orogeny, Assembly of Gondwana

INTRODUCTION

Tectonothermal activity in intraplate orogenic belts is commonly linked via far-field stresses to contemporaneous plate convergence in collisional or accretionary orogenic belts (Cawood and others, 2009; Aitken and others, 2013; Raimondo and others, 2014). Active examples include Cenozoic intraplate deformation of central Asia responding to India-Asia collision (Yang and Liu, 2009; Yin, 2010; Cunningham, 2013; Raimondo and others, 2014) and the Cenozoic Central Andes Orogen responding to flat-slab subduction of the Nazca plate (Ramos and others, 2002; Ramos and Folguera, 2009). Older intraplate events include the Neoproterozoic-Paleozoic Petermann and Alice Springs orogenies of central Australia (Atiken and others, 2009, 2013; Raimondo and others, 2010, 2014) and the Borborema Province of northeastern Brazil (Tommasi and Vauchez, 1997; Neves, 2003). However, linking intraplate and plate margin processes in ancient examples is hindered by the absence of a preserved kinematic framework.

Early to mid-Paleozoic orogenesis in South China is considered intraplate in origin based on an absence of sutures or other evidence for closure of an ocean basin or plate margin of appropriate age, as well as the presence of pre-, syn-, and post-orogenic sedimentary units that can be correlated across the region (Shu and

\footnotetext{
* State Key Laboratory of Geological Processes and Mineral Resources, Center for Global Tectonics, China University of Geosciences, Wuhan, 430074, China

** State Key Laboratory of Biogeology and Environmental Geology, School of Earth Sciences, China University of Geosciences, Wuhan, 430074, China

*** Department of Earth Sciences, University of St. Andrews, North Street, St. Andrews KY16 9AL, United Kingdom

$\$$ Centre for Exploration Targeting, School of Earth and Environment, University of Western Australia, 35 Stirling Highway, Crawley Western Australia, 6009, Australia

${ }^{\dagger}$ Corresponding author: xuyajun19@163.com (YA-JUN XU); Tel.: +86 27 67883001, Fax: +86 27 67883002
} 
others, 2008, 2014; Faure and others, 2009; Li and others, 2010; Chen and others, 2010, 2012b, 2014; Wang and others, 2010; Charvet and others, 2010; Charvet, 2013). This event is referred to as the Kwangsian Orogeny (Ting, 1929) but the region affected has also been variously termed the South China Caledonian fold belt (Ren, 1991; Charvet and others, 1999; Faure and others, 2009) or the Wuyi-Yunkai Orogen ( $\mathrm{Li}$ and others, 2010). Orogenesis is marked by a regional unconformity between pre-Devonian and Devonian strata, and widespread magmatic and metamorphic events are dated between 460 to $400 \mathrm{Ma}$ in the southeastern part of the South China Craton (Li and others, 2010; Wang and others, 2011c, 2012b, 2013c; Xu and others, 2011; Zhang and others, 2012; Yao and others, 2012; Wang and others, 2013a; Xia, and others, 2014). On the basis of the temporal equivalence of tectonothermal activity, orogenesis likely extended northeast to include activity on the Korean peninsula (Kim and others, 2006, 2014) and southwest into the Indochina Block (Carter and others, 2001; Nagy and others, 2001; Roger and others, 2007; Lepvrier and others, 2008; Usuki and others, 2009). The tectonic driver for the Kwangsian Orogeny has been related to a far-field response to the subduction/collision between the South China and North China blocks during the Silurian (Wang and others, 2007) or plate interaction on the northern margin of east Gondwana (Li, 1998; Li and others, 2010; Wang and others, 2010). But the controls on the localization of intraplate deformation to specific regions such as South China are unresolved and are the focus of this paper. We present an analysis of the geology of South China including the potential for variations in lithospheric rheology related to the disposition of inherited lithospheric discontinuities, the impact of heat flow and potential thermal blanketing effects, and the effects of fluid alteration on lithologic properties. Such features are known to play a significant role in intraplate deformation of other regions and we argue that in South China they enabled stress localization and intraplate deformation well removed from an active plate margin.

GEOLOGICAL SETTING

The South China Craton incorporates the Yangtze Block to the northwest and the Cathaysia Block to the southeast (fig. 1A). These blocks include Archean and Paleoproterozoic basement units that were assembled and accreted via a series of early to mid-Neoproterozoic accretionary arc complexes during the assembly of Rodinia (Zhao and Cawood, 1999; Zhao and others, 2011; Zhou and others, 2002; Cawood and others, 2013; Wang and others, 2013e). A failed continental rift system of mid-Neoproterozoic age (820-725 Ma, Wang and Li, 2003; Zhang and others, 2008) occurs within the central (Nanhua Rift) and western (Kangdian Rift) portions of the craton (fig. 1A and fig. 1B). These rifts are characterized by widespread bimodal magmatism and associated sedimentary successions, and their formation is related to breakup of the Rodinia supercontinent (Wang and Li, 2003; Li and others, 2003, 2008a; Li and others, 2008b; Shu and others, 2011; Zhao and Cawood, 2012).

The Neoproterozoic succession in South China passes conformably into a lower Paleozoic succession that can be traced across the craton and which shows significant facies variation (fig. 1C). On the Cathaysia Block, Cambrian and Ordovician strata are siliciclastic-dominated with interstratified limestone. Abundant sedimentary structures include rhythmic bedding, cross-bedding, and wavy scour marks indicating accumulation in a littoral-neritic depositional environment (Wang and others, 2010; Shu and others, 2014). Silurian sequences are generally absent, except for the QinzhouFangchenggang area in the south. In the eastern Yangtze Block, early Cambrian strata are characterized by black shale and chert sequences developed in a deep-water basin that shallowed upwards into an interstratified carbonate-siliciclastic succession during the late Cambrian to Ordovician. The Silurian succession is separated from the Ordovician strata by an angular unconformity but the contact changes to a disconformity to the west 


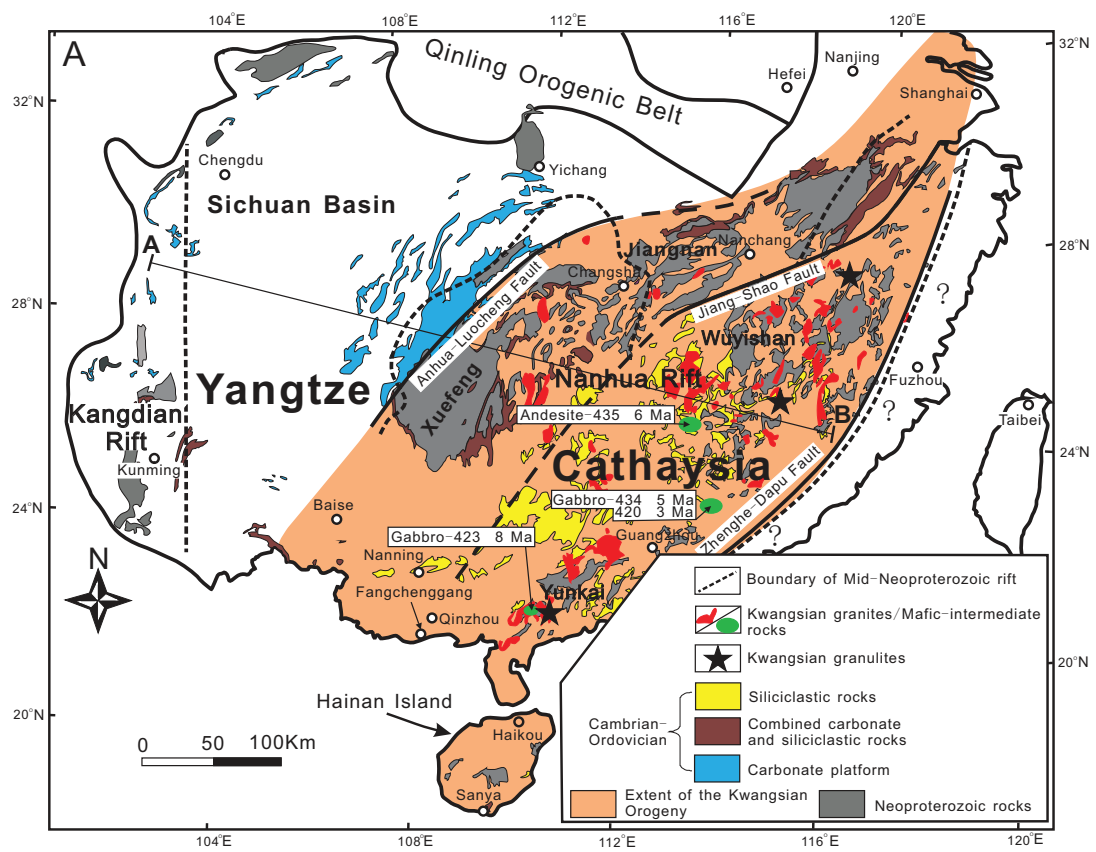

B Middle Neoproterozoic intracontinental rift

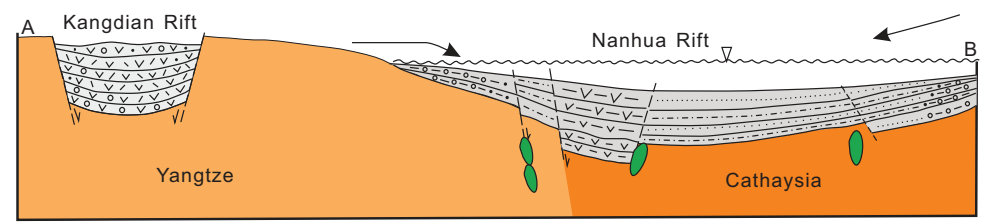

C Pre-Kwangsian sedimentary facies distribution

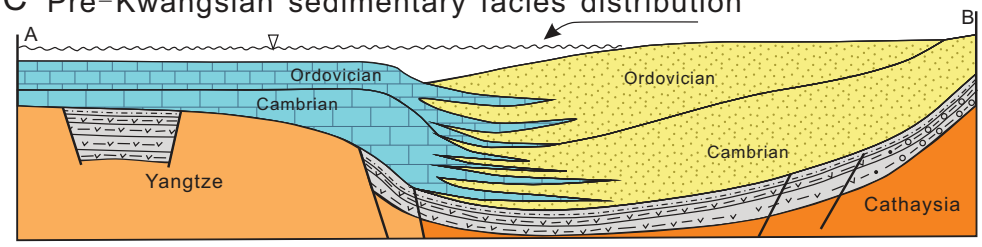

D The Kwangsian deformation and magmatism

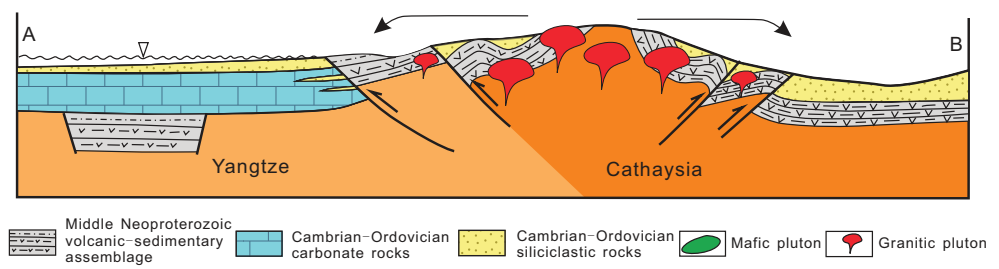

Fig. 1. (A) Simplified geological map of the South China Craton showing change of lithological assemblage in the Cambrian-Ordovician succession and distribution of Neoproterozoic rocks, the Kwangsian granites, mafic-intermediate rocks and granulites. The boundary of the mid-Neoproterozoic rift is from Wang and $\mathrm{Li}$ (2003). The locations of the Kwangsian granulites are from Chen and Zhuang (1994), Yu and others $(2005,2014 \mathrm{a})$ and Wang and others $(2012 \mathrm{~b})$. (B) A schematic cross section of South China during the rift phase (modified from Wang and Li, 2003); (C) a schematic cross section showing change of lithological assemblage during the Early Paleozoic (modified from Wang and others, 2010); (D) a schematic crosssection showing structural patterns during the Kwangsian Orogeny. 


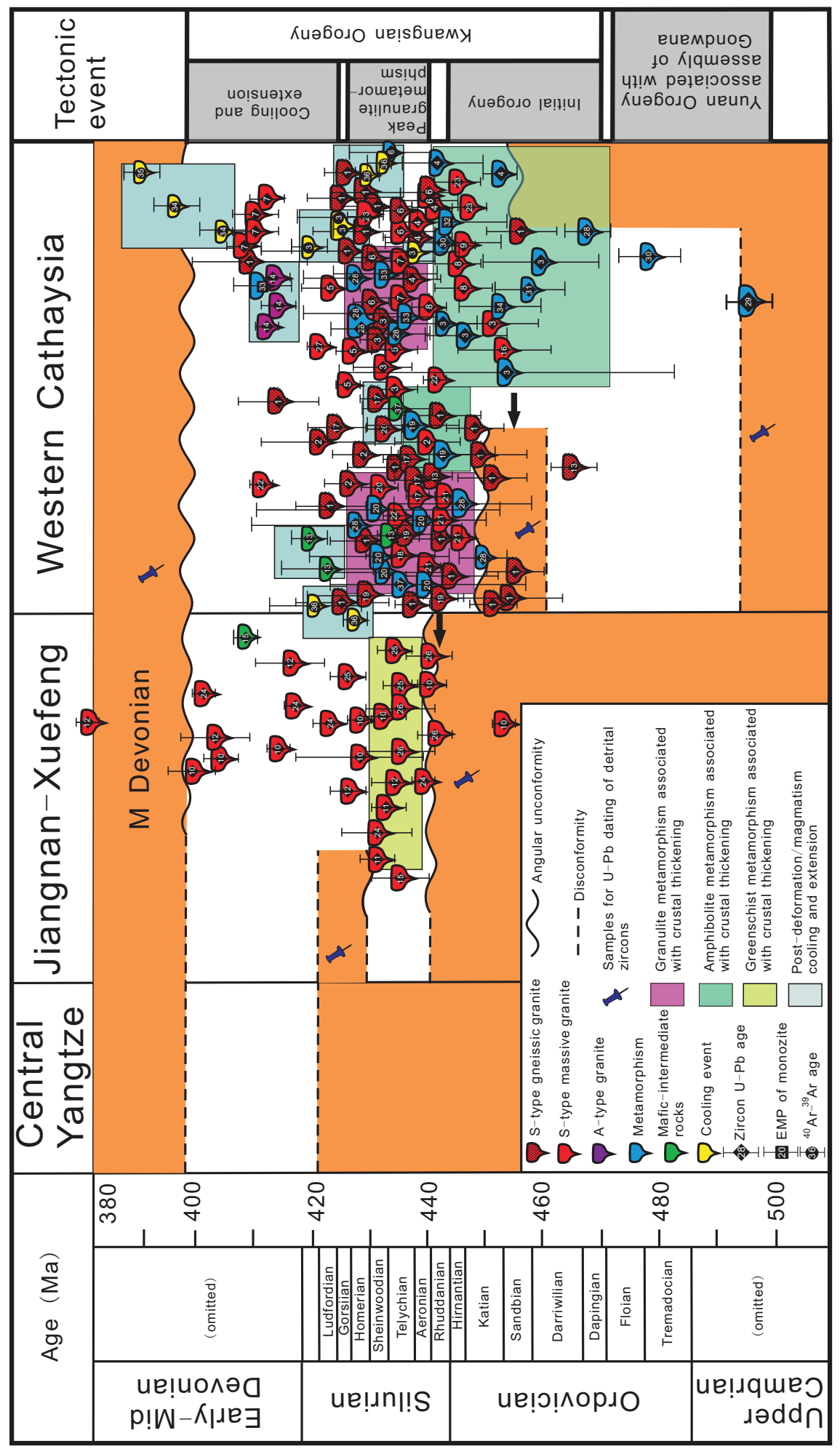


(Wang and others, 2010; Yu and others, 2014b). In the central-western Yangtze, a carbonate platform prevailed during the Cambrian and Ordovician (fig. 1C). Silurian strata conformably overlie the Cambrian-Ordovician succession and mark a change to siliciclastic sedimentation (fig. 2) (Wang and others, 2010; Xu and others, 2013). U-Pb ages and Hf isotope compositions of detrital zircons preserved in the early Paleozoic siliciclastic rocks reveal that these rocks contain a large amount of detritus derived from late Mesoproterozoic ( $c a .1120 \mathrm{Ma}$ ), early Neoproterozoic ( $c a .960 \mathrm{Ma}$ ), and late Neoproterozoic ( $c a .590 \mathrm{Ma}$ ) source rocks (Wang and others, 2010; Yao and others, 2011; Xu and others, 2013, 2014a; Yao and others, 2014a, 2014b). Integrated with paleocurrent data for Cambrian - Lower Silurian sandstones, which indicate flow from the southeast, the sources have been considered to lie beyond the current exposed limit of the craton in East Gondwana (Wang and others, 2010; Cawood and others, 2013; $\mathrm{Xu}$ and others, 2013).

CHARACTER AND DISTRIBUTION OF THE KWANGSIAN OROGENY

Regional-scale tectonothermal activity associated with the Kwangsian Orogeny is focused in southeastern South China to the east of the Jiangnan-Xuefeng Domain and to the west of the Zhenghe-Dapu Fault (fig. 1A) (Charvet and others, 2010; Shu and others, 2014).

Kwangsian metamorphism ranges from amphibolite facies in Cathaysia to greenschist facies in the eastern Yangtze (Wang and others, 2012b; Shu and others, 2014). In addition, isolated areas of upper amphibolite and granulite-facies metamorphic rocks crop out in the Wuyishan and Yunkai domains in the northeastern and southwestern parts of the Cathaysia Block, respectively (fig. 1A) (Chen and Zhuang, 1994; Yu and others, 2005, 2014a; Wang and others, 2012b). Zircon U-Pb and monazite U-Th-Pb dating of migmatized amphibolites and granulite-facies pelites yield ages in the range 460 to $423 \mathrm{Ma}$ with a peak at $435 \mathrm{Ma}$ interpreted as the time of orogenic relatedmetamorphism (fig. 2; Supplementary Dataset, http:/ / earth.geology.yale.edu/\% 7eajs/ SupplementaryData/2016/Xu) (Yu and others, 2005, 2014a; Charvet and others, 2010; Li and others, 2010; Wang and others, 2013a). Ar-Ar dating of biotite, muscovite and hornblende from mylonitic rocks in the Wuyishan and Yunkai domains yielded cooling ages in the range 438 to $406 \mathrm{Ma}$ (fig. 2; Supplementary Dataset, http:/ / earth.geology. yale.edu/\% 7eajs/SupplementaryData/2016/Xu; Shu and others, 1999, 2008, 2014; Li and others, 2010; Xu and others, 2011). These geochronological data, integrated with a clockwise P-T path displaying isothermal decompression (Zhao and Cawood, 1999; Li and others, 2010; Wang and others, 2012b, 2013c; Feng and others, 2014), suggest an overall regime of crustal thickening at 460 to 435 Ma followed by exhumation and cooling from 435 to $400 \mathrm{Ma}$.

Fig. 2. Schematic stratigraphic relations and tectonothermal activity during the Cambrian to Devonian in the South China Craton. Orange areas indicate sedimentation, whereas white areas indicate absence of strata. Black arrows suggest the boundaries of litho- and biofacies change responding to the Kwangsian Orogeny (after Chen and others, 2014). Numbers on data points refer to the following sources: 1 (Wang and others, 2011c), 2 (Wang and others, 2007), 3 (Li and others, 2010), 4 (Liu and others, 2010), 5 (Shu and others, 2014), 6 (Xu and others, 2011), 7 (Xia and others, 2014), 8 (Xu and others, 2009), 9 (Zeng and others, 2008), 10 (Zhang and others, 2012a), 11 (Guan and others, 2014), 12 (Zhao and others, 2013), 13 (Wang and others, 2013a), 14 (Feng and others, 2014), 15 (Zhong and others, 2013), 16 (Yang and others, 2010), 17 (Wang and others, 2013c), 18 (Huang and others, 2013), 19 (Wan and others, 2010), 20 (Chen and others, 2012a), 21 (Wang and others, 2013b), 22 (Wang and others, 2011b), 23 (Zhang and others, 2010a), 24 (Zhang and others, 2010b), 25 (Zhang and others, 2011b), 26 (Zhang and others, 2011c), 27 (Yang and others, 2014), 28 (Wang and others, 2012b), 29 (Zhang and others, 2011a), 30 (Yu and others, 2005), 31 (Wan and others, 2007), 32 (Chen and others, 2008), 33 (Charvet and others, 2010), 34 (Faure and others, 2009), 35 (Shu and others, 1999), 36 (Shu and others, 2008), 37 (Yao and others, 2012), 38 (Yu and others, 2014a). Data details are given in Appendix table A1. 
Deformation features include widespread folding and thrusting with ductile shearing (Shu and others, 2014). Kinematic indicators (shearing foliation, stretching lineation and asymmetric fabric elements) change from top-to-the-southeast in the southeastern Cathaysia Block to top-to-the-northwest in the northwest portion of the block and are interpreted to form a positive-flower structure (fig. 1D) (Shu and others, 2008, 2014; Charvet and others, 2010).

Voluminous gneissic granite and massive granite occur between the ZhengheDapu Fault and the Anhua-Luocheng Fault (fig. 1A). These plutons are mainly S-type peraluminous granites that originated from crustal anatexis and range in age from 460 to $400 \mathrm{Ma}$ (fig. 2) (Charvet and others, 1996, 1999, 2010; Wan and others, 2007, 2010; Wang and others, 2007, 2011c; Li and others, 2010; Yang and others, 2010; Zhang and others, 2010a, 2010b). In addition, minor A-type granites and associated mafic intrusions ranging in age from 435 to $410 \mathrm{Ma}$ outcrop in the central Cathaysia Block (fig. 2) (Yao and others, 2012; Wang and others, 2013c; Zhong and others, 2014; Feng and others, 2014).

Stratigraphic and biostratigraphic data from east of the Jiangnan-Xuefeng Domain suggest that the Kwangsian Orogeny developed diachronously from south to north (Chen and others, 2010, 2012b, 2014). Uplift of the Cathaysian crust as a response to orogenesis was initially focused along the southeastern coast of South China in the Sandbian age of the Late Ordovician (fig. 2) (ca. $455 \mathrm{Ma}$, Walker and others, 2013). This was marked by a change in sedimentary facies to the east of Yunkai Domain from graptolitic shale to nearshore shallow-water, coarse clastic rocks, with the development of an angular unconformity between upper Ordovician and Devonian strata. The event progressively propagated northward and affected the southeastern margin of the Yangtze Block during the late Rhuddannian stage of the early Silurian (fig. 2) (ca. $440 \mathrm{Ma}$, Walker and others, 2013), and is recorded by the angular unconformity between Silurian and Devonian strata around the Jiangnan-Xuefeng Domain. U-Pb detrital zircon age patterns from the Silurian-Devonian strata display a similar age distribution to those of underlying Cambrian-Ordovician strata but with additional input of detritus from early to mid-Neoproterozoic accretionary arc complexes (870-820 Ma) and continental rift succession (820-725 Ma) and the Kwangsian granites $(0.46-0.4 \mathrm{Ga}$ ) (figs. 3A, 3B, 3C, and 3D) ( $\mathrm{Xu}$ and others, 2012; $\mathrm{Yu}$ and others, 2014b). Thus, these patterns indicate uplift and exposure of the Cathaysian basement and the syn-orogenic granites.

EARLY PALEOZOIC LITHOSPHERIC ARCHITECTURE OF SOUTH CHINA AND STRAIN LOCATION

Causes for the localization of stress in a continental interior removed from a plate margin, during intraplate orogenesis, remain enigmatic (Braun and Shaw, 1998; Sandiford and others, 2004). It is generally accepted that strain localization reflects spatial and temporal variation in lithospheric strength (Raimondo and others, 2014). Strong lithosphere permits transmission of stresses sourced from plate boundaries, whereas weak lithosphere tends to form sites of stress accumulation (Ziegler and others, 1995; Heidbach and others, 2010, Raimondo and others, 2014). Lithospheric strength is related to rheological architecture and there are two end-member models of lithospheric rheology, which are colloquially referred to as the "Jelly Sandwich" (Chen and Molnar, 1983) and "Crème Brûlée" models (Maggi and others, 2000; Jackson, 2002). These models have been mainly applied to modern tectonic settings such as the Himalayas (Burov and Watts, 2006; Chen and others, 2014), and their applicability to understanding the behavior of ancient lithosphere is limited due to subsequent tectonic reworking modifying lithospheric structure. Factors likely to influence lithospheric strength, whether in modern or ancient settings, include inherited lithospheric discontinuities, crustal heat flow, and weakening of the lithosphere through fluid alteration (Raimondo and others, 2014). 


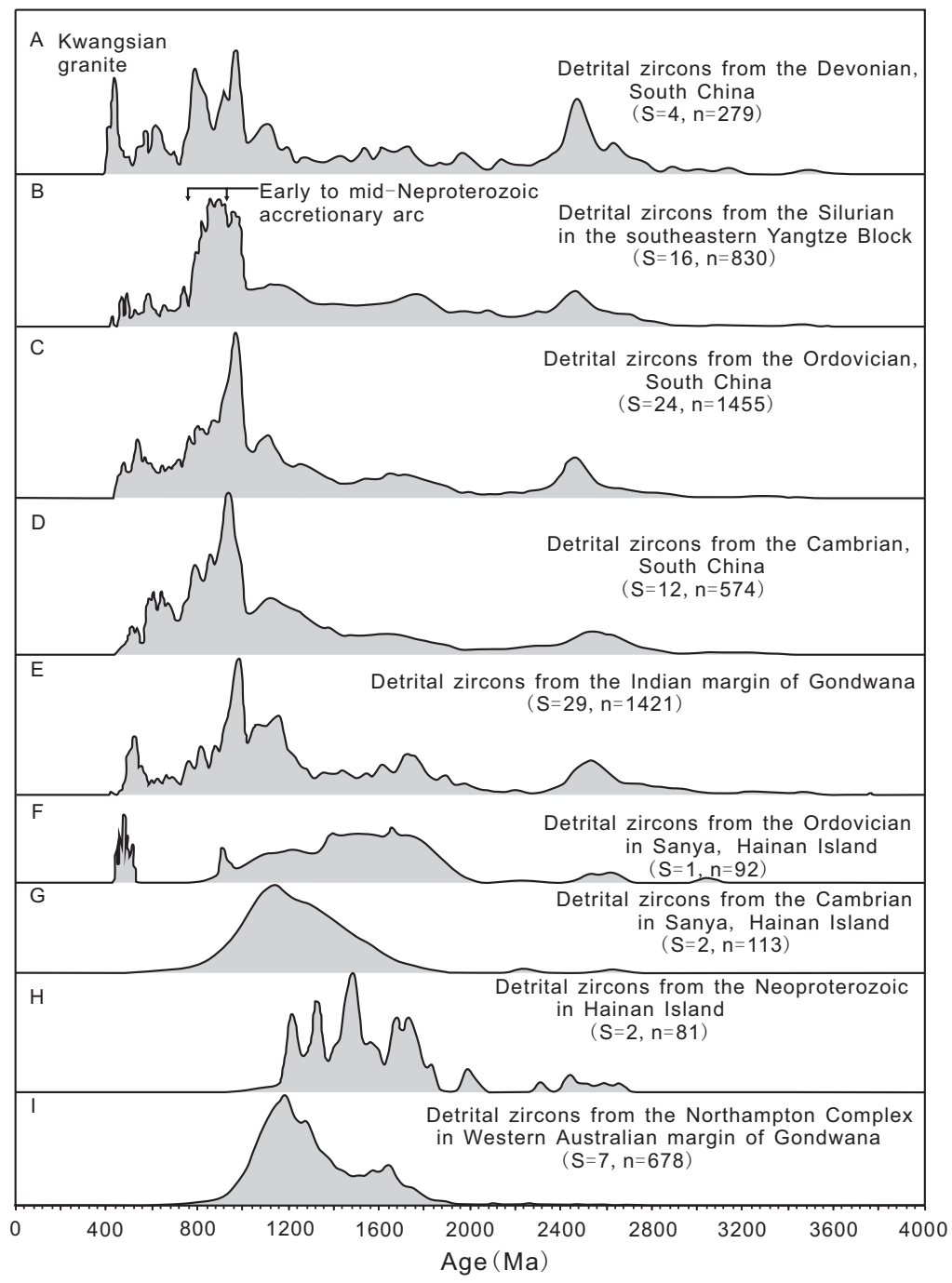

Fig. 3. Summary of detrital zircon age distributions of samples from the early Paleozoic-Devonian in South China (A, B, C, D) (data from Wang and others, 2010; Xiang and Shu, 2010; Yao and others, 2011; Xu and others, 2012, 2013, 2014a; Wang and others, 2014a; Yu and others, 2014b), North India margin of Gondwana (E) (data from Gehrels and others, 2006a, 2006b; Myrow and others, 2009, 2010; Hughes and others, 2011; Long and others, 2011; McQuarrie and others, 2008, 2013), Sanya in Hainan Island (F, G, H) (data from Xu and others, 2014b) and Western Australia (I) (data from Ksienzyk and others, 2012). Detrital zircon age distributions of the early Paleozoic sequences from South China are similar to that of the Himalaya region of North India, suggesting South China was linked to North India (Xu and others, 2013, 2014a). Detrital zircon age distributions of samples from strata across the Cambrian to Ordovician unconformity in Hainan Island show a change of sediments sourcing from Western Australia in the Cambrian to mixed sources including Western Australia and South China (including Hainan Island) in the Ordovician, indicating an amalgamation of South China-India and Western Australia along the Kuunga suture $(\mathrm{Xu}$ and others, $2014 \mathrm{~b}) . \mathrm{s}=$ number of samples, $\mathrm{n}=$ total number of analyses. All data based on analyses within $90 \%-110 \%$ of concordance. Ages greater than $1000 \mathrm{Ma}$ calculated using ${ }^{207} \mathrm{~Pb} /{ }^{206} \mathrm{~Pb}$ ratios, and ages less than $1000 \mathrm{Ma}$ calculated from ${ }^{206} \mathrm{~Pb} /{ }^{238} \mathrm{U}$ ratios. Data details and references are given in supplementary tables A2-A4 (http://earth.geology.yale.edu/ ajs/SupplementaryData/2016/ XuTables). 


\section{Inherited Lithospheric Discontinuities}

The presence and orientation of pre-existing lithospheric discontinuities reflecting the amalgamation of contrasting lithologic assemblages has been invoked as an important control in the localization of subsequent intraplate activity (Gorczyk and others, 2013; Cloetingh and others, 2013; Raimodo and others, 2014). Penetrative faults and suture zones have the potential to constitute significant rheological discontinuities and provide favored sites for strain localization (Stewart and others, 2000; Braun and Shaw, 2001; Holdsworth and others, 2001; Gueydan and others, 2003; Marsh and others, 2009; Gorczyk and others, 2013).

The South China Carton formed through amalgamation of the Yangtze and Cathaysia blocks along the early Neoproterozoic Jiang-Shao suture zone currently exposed along the Jiang-Shao Fault. The suture zone is marked by the juxtaposition of mafic-ultramafic intrusions, MORB-affinity tholeiite, boninite, and arc-affinity igneous and associated sedimentary rocks. (Zhao and Cawood, 2012; Zhao and Asimow, 2014). Thus, the Jiang-Shao suture marks a fundamental discontinuity within the South China lithosphere and displays abrupt lateral variation in rock compositions and physical properties (Zhang and others, 2013; Lu and others, 2014; Deng and others, 2014). The Jiang-Shao suture zone, along with the adjoining segments of the Yangtze and Cathaysia blocks, were the sites of lithospheric extension in the mid-Neoproterozoic responding to the breakup of Rodinia and forming the Nanhua rift. The rift was the locus for accumulation of a volcanic-sedimentary assemblage and related plutonic activity (fig. 1B). Sediment thickness within the rift reached $5000 \mathrm{~m}$ (Wang and Li, 2003). An array of lithospheric-scale faults was active during rifting including the Anhua-Luocheng, Jiang-Shao, and Zhenghe-Dapu faults (fig. 1A) (Charvet and others, 1996, 2010; Faure and others, 2009; Wang and others, 2010; Zhang and others, 2012; Charvet, 2013) and resulting extension very likely reduced the thickness of continental lithosphere in the southeast part of South China. Thus, assembly of South China and subsequent lithospheric extension of the craton during the mid-Neoproterozoic resulted in a mechanically weakened zone of lithosphere. This zone was the locus for further re-activation during the Kwangsian Orogeny.

\section{Thermal Effects}

The thermal structure of lithosphere exerts a first-order control on its strength (Sandiford and McLaren, 2002; Sandiford and others, 2002; Jackson and others, 2008; Korhonen and Johnson, 2015). Lateral variations in the geotherm may be responsible for rheological heterogeneities in the continental lithosphere and thus influence the localization of intraplate deformation (McLaren and Sandiford, 2001; Sandiford and others, 2001; Raimondo and others, 2014). The formation of an anomalous thermal domain depends on two factors: (1) local enrichment of radiogenic heat-producing elements (mainly U, Th and K) (Neves and others, 2008; Vilà, and others, 2010; Bea, 2012) and (2) efficient thermal insulation such as that provided by a thick sedimentary blanket (Sandiford and Hand, 1998; Hand and Sandiford, 1999; Sandiford and McLaren, 2002). Mantle heat flux is also significant at regional scales, but is less easy to quantify (Neves and others, 2008). In general, U, Th and K constitute incompatible elements in the mantle and are preferentially concentrated in the crust. The distribution of $\mathrm{U}$, Th and $\mathrm{K}$ within the crust varies as a result of petrogenetic processes and they are enriched in felsic rocks and their sedimentary and low grade metamorphic derivates, especially granites and siliciclastic rocks (Vilà and others, 2010).

The Neoproterozoic continental crust of South China is characterized by widespread emplacement of granite, related to the assembly of the South China Craton and the mid-Neoproterozoic formation of continental rift systems ( $\mathrm{Li}$ and others, 2003; Li and others, 2008b; Wang and others, 2011a; Wang and others, 2014b). These granites 


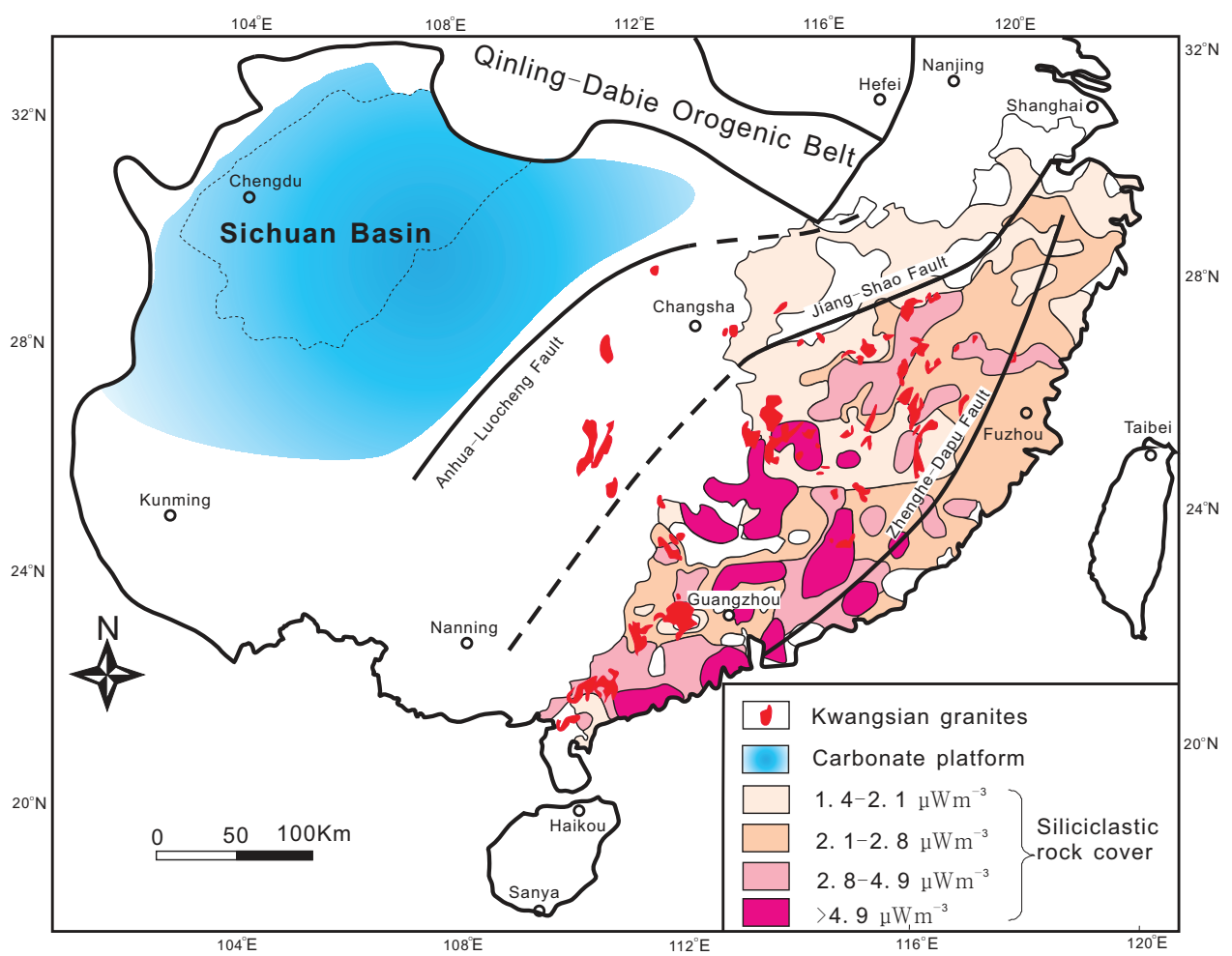

Fig. 4. Distribution of heat production of the southeastern part of South China (modified from Zhao and others, 1995). The distribution of Kwangsian granites shows the area of Kwangsian deformation.

have average heat production values of $3.0 \mu \mathrm{Wm}^{-3}$ (Zhao and others, 1995), more than twice that of typical continental crust $\left(1-1.2 \mu \mathrm{Wm}^{-3}\right.$, Bea, 2012).

The extent of intraplate deformation during the Kwangsian Orogeny does not display a direct correspondence with the areas of Neoproterozoic rocks with anomalously high heat production (fig. 1A). This is because lithospheric weakening related to thermal effects also incorporates effects from thermal insulation provided by a thick sedimentary cover above a high heat producing basement (Sandiford and Hand, 1998; Hand and Sandiford, 1999; Sandiford and McLaren, 2002). Late Neoproterozoic to Ordovician sedimentary rocks predating the Kwangsian Orogeny range from a siliciclastic dominated succession in the Cathaysia interior to an interstratified carbonatesiliciclastic succession in the eastern Yangtze and a carbonate-dominated succession in the central Yangtze (fig. 1C) (Wang and others, 2010; Xu and others, 2013). In general, siliciclastic rocks have higher heat production than carbonate-rich sedimentary rocks (Vilà and others, 2010). In the case of South China, the average heat production of late Neoproterozoic-Ordovician siliciclastic rocks developed in the southeastern part of the craton range from 2.13 to $2.43 \mu \mathrm{Wm}^{-3}$ (Zhao and others, 1995), and are higher than the worldwide statistical average value of $1.19 \mu \mathrm{Wm}^{-3}$ for siliciclastic rocks (Vilà and others, 2010). Consequently, the Cathaysia Block and neighboring regions covered by siliciclastic rocks display the highest heat production, whereas the crust beneath the Cenozoic Sichuan Basin in the northwest of the Yangtze Block acted as a cold, stable domain (fig. 4). This is also consistent with seismic observations, suggesting the abrupt lateral variation of crustal structure near the 
eastern margin of the current Sichuan Basin (Zhang and others, 2013; Lu and others, 2014). For example, shear wave splitting measurements in the Sichuan Basin show no anisotropy, whereas belt-parallel anisotropy oriented NE-SW occurs along the southeastern margin of the Yangtze Block (Lu and others, 2014).

\section{Fluid Effects}

Fluids play a role in most orogenic processes (Miller and others, 2002; Jackson and others, 2004; Yardley, 2009; Putnis and Austrheim, 2010; Raimondo and others, 2014). Their effects include lithospheric weakening by metasomatic alteration (Jackson and others, 2004; Niemeijer and Spiers, 2005), fracturing induced by increased fluid pressures and reaction-induced volume change (Jamtveit and others, 2008, 2009; Wannamaker and others, 2009), and crustal anatexis generated by fluid fluxing (Miller and others, 2002; Brown, 2013). The weakening of large-scale continental lithosphere by fluid infiltration requires a plausible deep crustal or mantle fluid source, which is not self-evident for dry and refractory continental lithosphere that has undergone multiple metamorphic cycles. Thus, external sources of fluid are often invoked (Raimondo and others, 2014), particularly where the ancient subducted slab or the breakdown of hydrous minerals produces significant fluid influx via dehydration reactions (Cartwright and Barnicoat, 2003; Barnes and others, 2004; Buick and others, 2008; Wannamaker and others, 2009).

In South China, Silurian gabbros (fig. 1A) exposed in the southern part of the Cathaysia Block are inferred to have been derived from a source modified by slab- and sediment-derived melts plus fluid fluxing from Neoproterozoic subduction associated with assembly of the South China Craton (Wang and others, 2013c). An additional source of fluid that may have affected crustal strength is from the breakdown of hydrous minerals. The petrogenesis of Kwangsian magmatic and metamorphic rocks suggests that the widespread granitic magma and migmatization in South China was generated from the anatexis of Precambrian rocks through the breakdown of hydrous minerals (Wan and others, 2007, 2010; Li and others, 2010; Liu and others, 2010; Wang and others, 2011c, 2012; Chen and others, 2012a; Zhang and others, 2012; Wang and others, 2013a; Xia and others, 2014). Thus, lithospheric weakening of the southeast part of South China was likely assisted by this fluid flux.

GEODYNAMIC MODEL FOR THE INTRAPLATE KWANGSIAN OROGENY

The plate kinematic framework for ancient orogenic systems is not preserved. However, temporal associations, and where available, spatial associations provide important data in linking plate margin and intraplate orogenic associations. The magmatic, deformational, metamorphic and stratigraphic events related to the Kwangsian Orogeny occurred between 460 to $400 \mathrm{Ma}$ (fig. 2). This involved an initial phase of orogenesis commencing at $c a .460 \mathrm{Ma}$ and extending to around 435 to $430 \mathrm{Ma}$ that involved reactivation and inversion of the Nanhua Basin, with associated crustal thickening and widespread anatexis (Yu and others, 2005; Wan and others, 2007, 2010; Li and others, 2010; Liu and others, 2010; Wang and others, 2011c, 2012; Chen and others, 2012a; Wang and others, 2013a; Shu and others, 2014; Xia and others, 2014). The later phases of orogenesis, related to exhumation and cooling of the thickened crustal pile, occurred between $c a$. 435 to $400 \mathrm{Ma}$ and were related to lithospheric extension (Yao and others, 2012; Wang and others, 2013c; Xia and others, 2014).

There is general agreement that the Kwangsian Orogeny occurred in an intraplate setting but a variety of geodynamic models have been proposed (fig. 5). Faure and others (2009) suggested an asymmetrical model involving northwest-directed intraplate underthrusting of the Cathaysia Block beneath the southeastern margin of the Yangtze Block along the Jiangshao Fault (fig. 5A). This model suggests a progressive propagation of orogenesis from northwest to southeast in Cathaysia and is thus at odds 

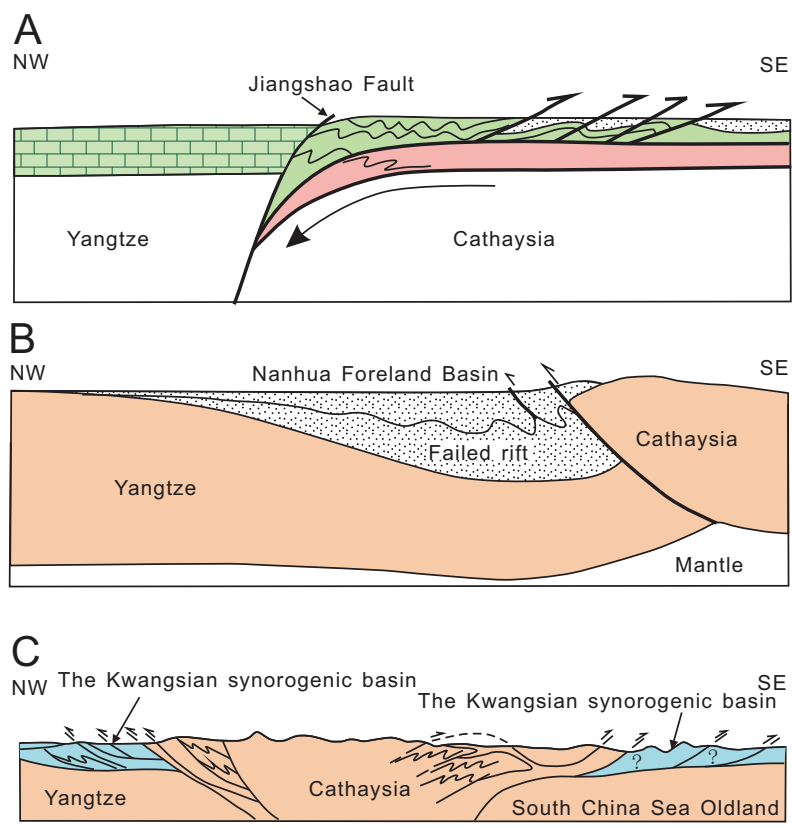

Fig. 5. The models for the Kwangsian Orogen suggested by (A) Faure and others (2009), (B) Li and others (2010), and (C) Shu and others, (2014).

with the observation that deformation migrated from the southeastern part of Cathaysia to the north towards the eastern margin of the Yangtze Block. The model is also inconsistent with the spatial change of metamorphic grade, as the highest grade rocks related to Kwangsian orogenesis occur within the Wuyishan and Yunkai domains (fig. 1A) away from the proposed zone of intraplate underthrusting, with lower grade rocks closer to the boundary. Li and others (2010) invoked a foreland basin model to explain the Kwangsian magmatism and metamorphism, with the inversion of the Nanhua rift basin through NW-directed overthrusting of the Cathaysia Block in response to South China colliding with India during the Ediacaran-Cambrian (fig. 5B) (see also Yao and others, 2014a, 2014b). However stratigraphic relations including provenance data for sedimentary rocks in South China indicate derivation from northern Gondwana, including India, with no evidence for an intervening oceanic basin during the Neoproterozoic-early Paleozoic (Jiang and others, 2003; Yu and others, 2008; Cawood and others, 2013; Xu and others, 2013, 2014a, 2014b). Furthermore, kinematic observations and geochronology of the ductile sheared rocks revealed a quasisymmetrical positive flower structure across the Cathaysia Block, with southeastward ductile thrusting in the southeastern Cathaysia Block and northwestward ductile thrusting in the northwestern Cathaysia Block with Ar-Ar ages of 430 to $390 \mathrm{Ma}$ (Shu and others, 2008, 2014; Charvet and others, 2010; Xu and others, 2011), which is inconsistent with asymmetric deformation developed in a foreland basin. Charvet and others (2010) and Shu and others (2014) proposed that the symmetrical shortening of the Nanhua rift occurred in response to intraplate subduction of "the split South China Sea Oldland", which they suggested represented a southern extension of the Cathaysia Block (Shu and others, 2014, p. 178) now beneath the current Cathaysia Block. This process resulted in inversion of pre-existing normal faults to form a positive flower structure across the Jiang-Shao Fault (fig. 5C). This symmetrical shortening 
model best accounts for the observed tectonothermal activity of the Kwangsian Orogeny but as with the other models it does not look at the broader scale geodynamic setting.

Figure 6 presents a tectonic model for the early Paleozoic including the timeframe of the Kwangsian Orogeny and places South China within its regional framework as part of the Gondwana supercontinent. Thus, it incorporates information on the temporally and spatially evolving nature of the plate boundaries around the Gondwana margin (Cawood, 2005; Cawood and Buchan, 2007; Cawood and others, 2007). In the late Neoproterozoic-Cambrian, the South China Craton was situated off northeast India (fig. 6A) (Jiang and others, 2003; Yu and others, 2008; Cawood and others, 2013; $\mathrm{Xu}$ and others, 2013). Abundant siliciclastic sediments, sourced from India and environs, were transported northward and deposited in the southern part of South China (Yu and others, 2008; Wang and others, 2010; Yao and others, 2011; Cawood and others, 2013; Xu and others, 2013, 2014a; Wang and others, 2014a; Yao and others, 2014a, 2014b). This is shown by similar age distributions of detrital zircons from the Cambrian to Ordovician sedimentary rocks to that of the North India margin (figs. 3C, 3D, and 3E). The united India-South China block was separated from Australia and Antarctica by an ocean basin (Xu and others, 2013, 2014b), now delineated by the Kuunga suture (Meert and others, 1995; Xu and others, 2014b; figs. 6A and 6B). The main lines of evidence for this intervening ocean include the remnants of accretionary prism and island arc rock types now forming parts of Japan (Isozaki and others, 2010, 2015; Isozaki 2011), Hainan Island (Ding and others, 2002; Xu and others, 2007, 2008), and the Song Ma belt (Findlay, 1997). The Cambrian succession in the Sanya Block at the southern end of current Hainan Island contains detritus derived from the West Australia Craton and has a distinctly different source from equivalent successions on the mainland of South China (figs. 3D and 3G) (Xu and others, 2014b). Furthermore, abundant specimens of the morphologically distinctive early middle Cambrian Xystriduriid trilobite genera Xystridura and Galahetes in the Sanya Block mimic their prolific occurrence in similar facies in Australia (Öpik, 1975; Kruse, 1990), but are absent from the well-studied middle Cambrian fauna of South China.

The ocean separating the Sanya Block (and Australia) from mainland South China (and India) closed during Cambrian-Ordovician time (fig. 6C). Evidence for this includes the presence of dikelokephalinid trilobites found in both South China and Australia in the Early Ordovician (Torsvik and Cocks, 2009) as well as the similarity of Early Devonian fresh water fish in South China, Vietnam, and the Canning Basin of Western Australia (Burrett and others, 1990). Paleomagnetic records revealed that India and Australia were separated by over $30^{\circ}$ of latitude at $c a .750 \mathrm{Ma}$ (Torsvik and others, 2001; Pisarevsky and others, 2003; Zhang and others, 2013a), but were adjacent to each other in the equatorial position by the end Neoproterozoic to early Paleozoic (ca. 600-520 Ma) in an assembled Gondwana (Powell and others, 1993; Powell and Pisarevsky, 2002). The middle Cambrian and Silurian paleomagnetic data from the South China Craton show that it was most probably in an equatorial position and close to Western Australia (Yang and others, 2004).

Closure of the Kuunga Ocean in the Cambrian-early Ordovician resulted in final assembly of East Gondwana and the development of a major mountain chain across the supercontinent (Boger and others, 2001; Gehrels and others, 2006a, 2006b; Squire and others, 2006; Cawood and Buchan, 2007; Cawood and others, 2007; Xu and others, 2013, 2014a; Gardner and others, 2014). Along the southern margin of South China this final assembly is expressed in the juxtaposition of the Sanya Block, Hainan Island (fig. 6C), with the remainder of the craton and is recorded in the development of unconformity between the Cambrian and Ordovician strata (named as the Yu'nanian Orogeny) and the compositional evolution of the detrital zircon signature, which 


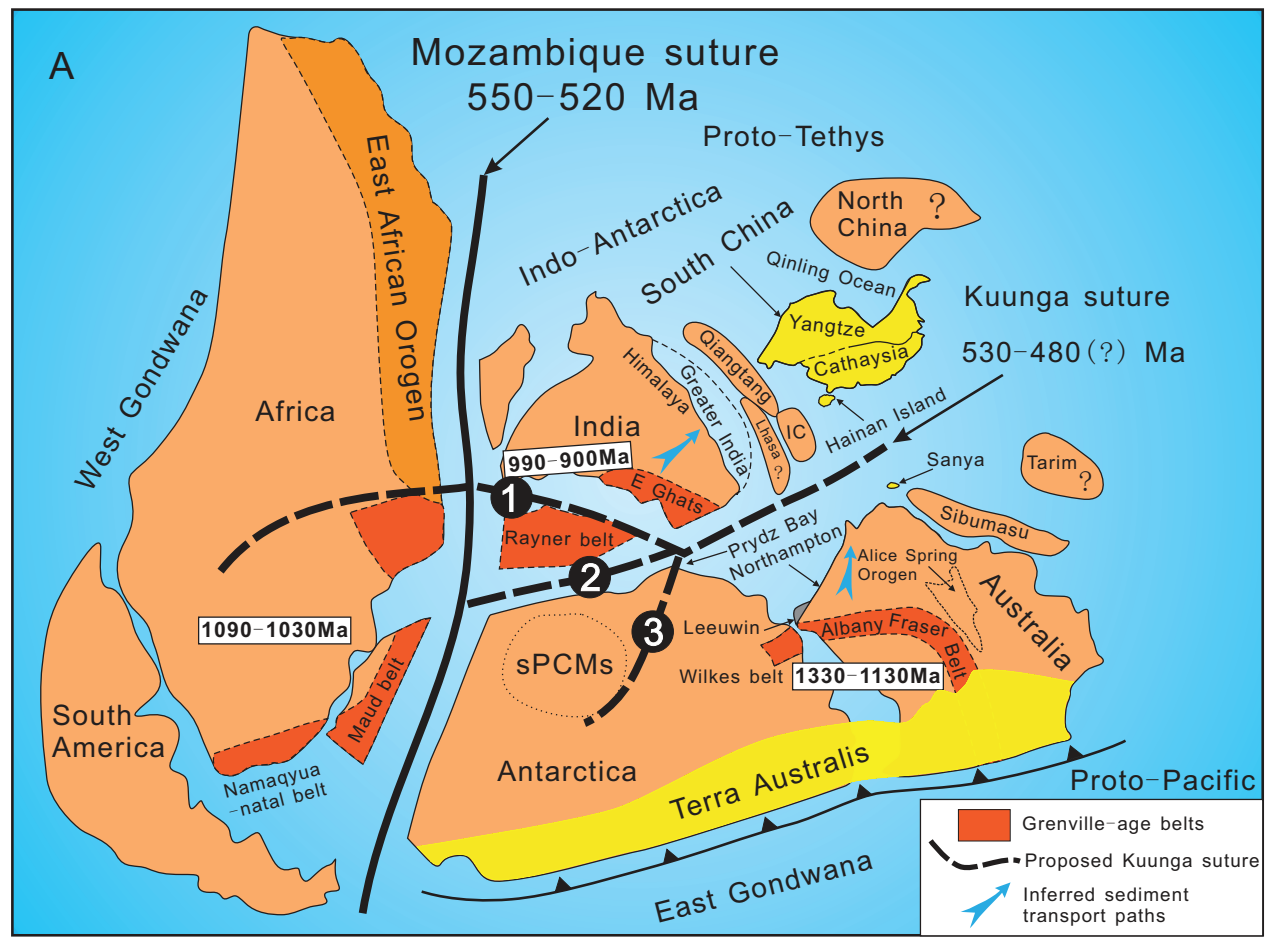

B Cambrian

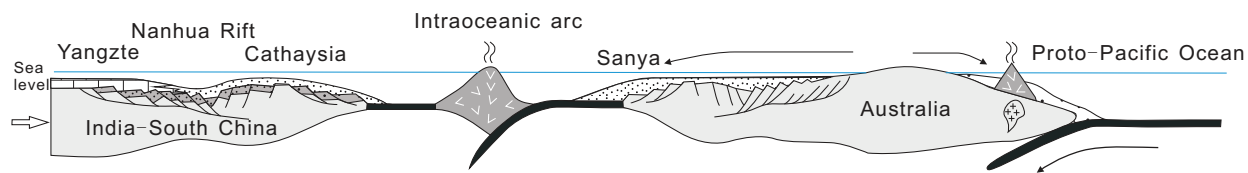

C Late Cambrian-Early Ordovician (Yu' nanian Orogeny)

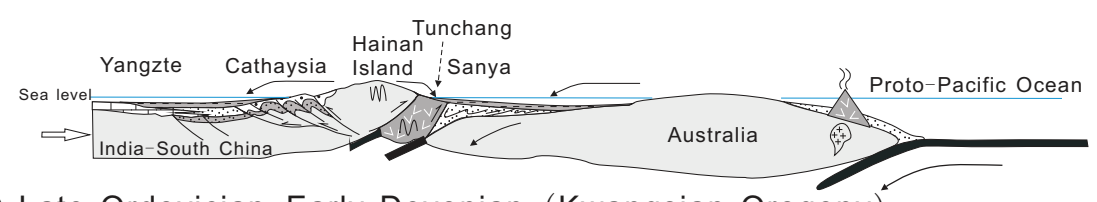

D Late Ordovician-Early Devonian (Kwangsian Orogeny)

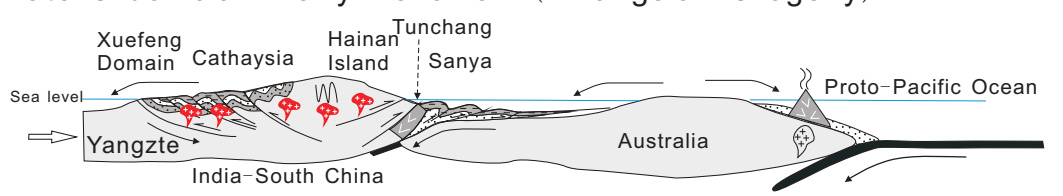

Fig. 6. (A) Simplified reconstruction of Gondwana showing the location of South China and northward continuation of the Kuunga suture (after Xu and others, 2014b). sPCMs - southern Prince Charles Mountains. (B, C) A series of sketches showing the amalgamation of the South China Craton and the Western Australia Craton during the Yu'nanian Orogeny and (D) development of the Kwangsian Orogeny.

resulted in the mixing of sources from South China and Australia (figs. 3F, 3G, 3H, and 3I) (Xu and others, 2014b). The $c a .490$ Ma metamorphic event in the southeastern part of South China (Zhang and others, 2011a) is also a likely expression of this event. 


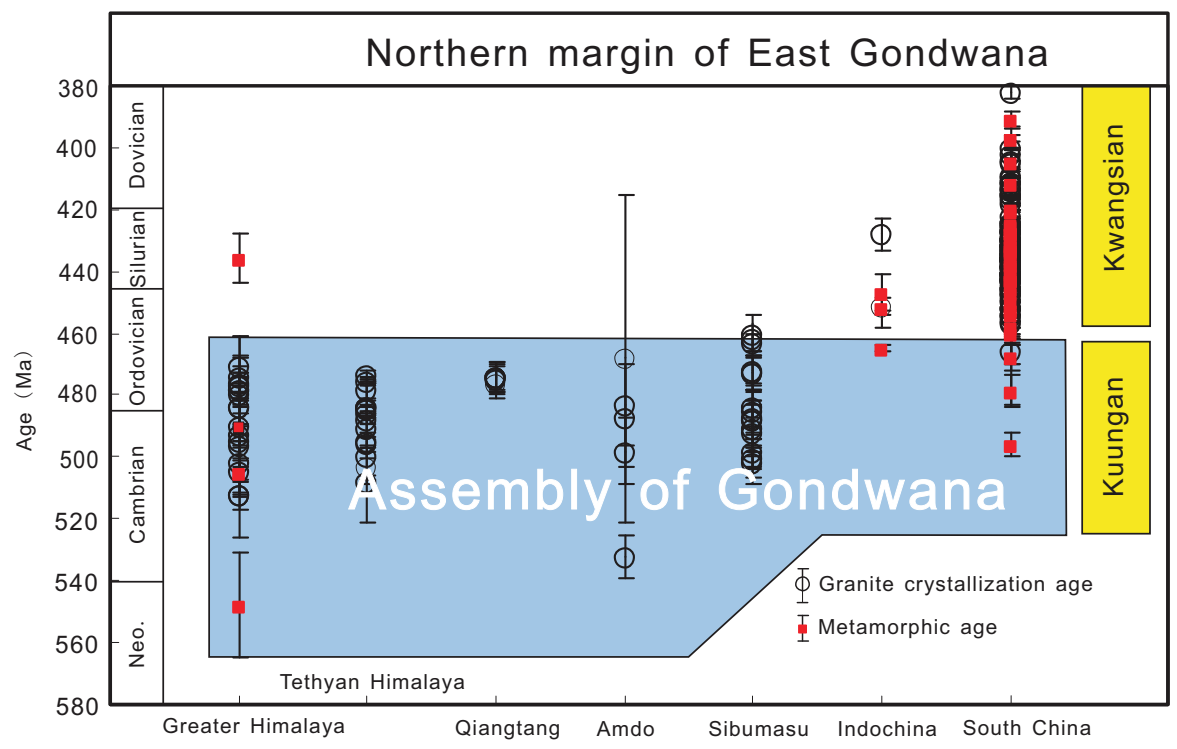

Fig. 7. The age-data of granitic rocks and metamorphism during the early Paleozoic orogeny from Himalaya to the Cathaysia Block of South China along the northern margin of East Gondwana (data from DeCelles and others, 2000; Lee and others, 2000; Roger and others, 2000; Nagy and others, 2001; Johnson and others, 2001; Catlos and others, 2002; Gehrels and others, 2006a, 2006b; Cawood and others, 2007; Lee and White, 2007; Liu and others, 2007; Song and others, 2007; Liu and others, 2009; Yin and others, 2010; Pullen and others, 2011; Guynn and others, 2012; Wang and others, 2012a; Zhang and others, 2012b; Lin and others, 2013; Wang and others, 2013d). Data details used in this plot are given in supplementary table A5 (http:/ / earth.geology.yale.edu/ ajs/SupplementaryData/2016/XuTables).

Kwangsian orogenesis post-dates Gondwana assembly (fig. 7) thus removing the Cathaysia Block from any spatial association with an active plate boundary. The South China Craton constituted part of the lithosphere of greater India (Cawood and others, 2013) with the north and northwestern margins of the Yangtze Block facing the protoTethys (fig. 6A). The nature of the plate margin of northern Gondwana is poorly constrained, in part due to its fragmentation into various continental blocks during opening and closure of the Tethys and subsequent overprinting associated with the India-Asia collision. Thus, the northern margin of the Yangtze Block has been proposed as both a passive and convergent margin (Wang and others, 2007; Wu and others, 2009; Dong and others, 2013). Wang and others (2007) suggested that deformation in South China is related to collision with North China along the Qinling belt in the period 460 to $400 \mathrm{Ma}$ following divergent two-sided subduction beneath the southern margin of the North China Craton and the northern margin of the South China Craton (Yangtze Block). The age of tectonothermal activity in the Qinling belt corresponds with that of Kwangsian orogenesis. However, the absence of any arc-related magmatism along the northern Yangtze margin (Wu and others, 2009; Dong and others, 2013, 2014) argues against the applicability of this model as a driver for Kwangsian orogenesis.

The timing of orogenesis in South China overlaps in part with intraplate events in central Australia (Appendix fig. A6-1). In particular, the overall time range of orogenesis from 460 to $400 \mathrm{Ma}$ corresponds with the commencement of the Alice Springs Orogeny (fig. 8). Tectonothermal activity during the Alice Springs event, especially its early history between $c a$. 460 to $400 \mathrm{Ma}$ has been tied to pulses of activity along the Terra Australis accretionary orogen reflecting coupling between the proto-Pacific oceanic plate and the Gondwana continental margin (Collins, 2002; Cawood, 2005). 


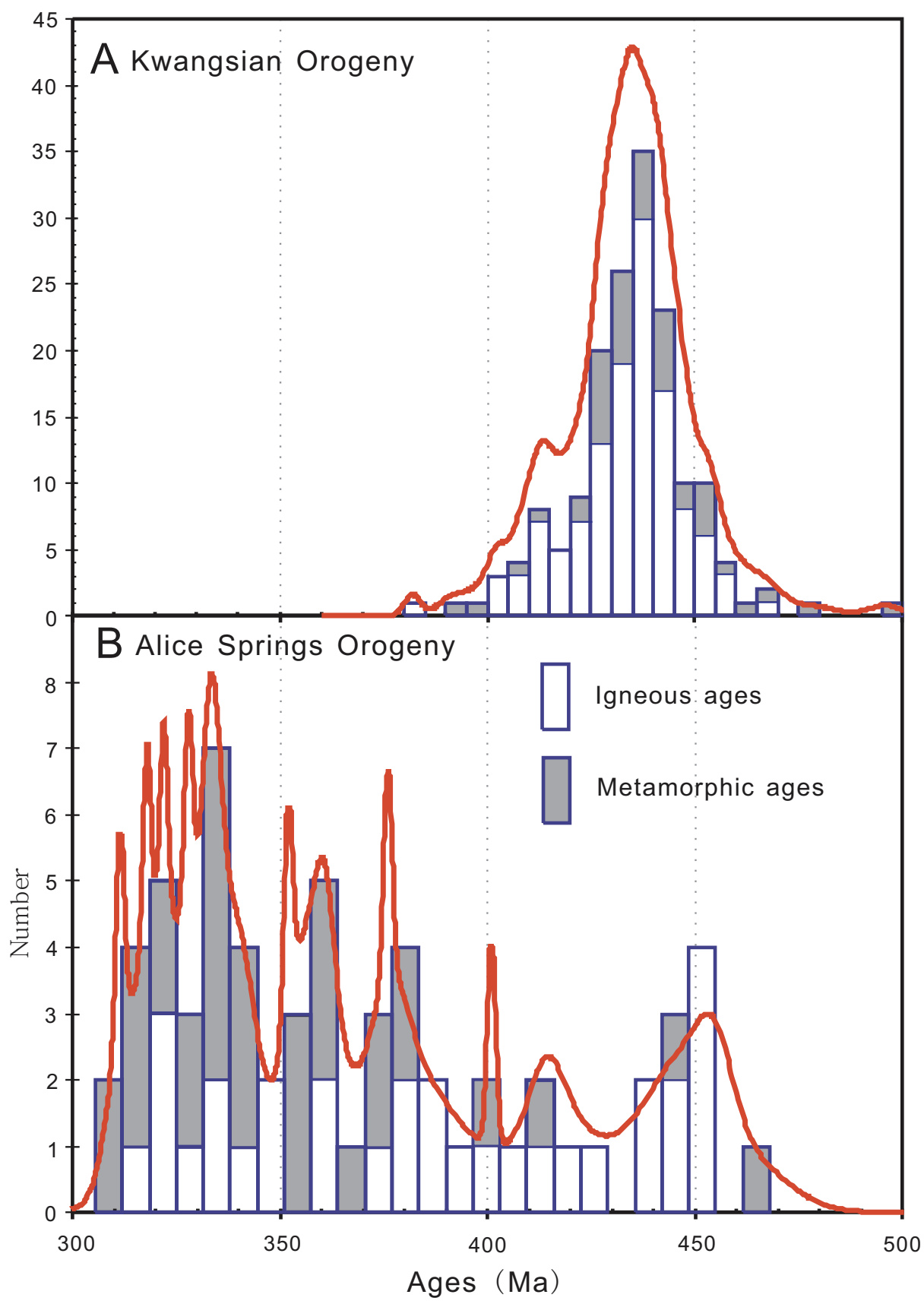

Fig. 8. Comparison of tectonothermal events during the Kwangsian Orogeny in South China and the Alice Springs orogeny in Central Australia. Data details and references about the Kwangsian Orogeny and the Alice Springs Orogeny are given in supplementary table A1 and tables A6 (http://earth.geology.yale.edu/ ajs/SupplementaryData/2016/XuTables), respectively.

There is little evidence for terrane accretion across the proto-Pacific-Gondwana boundary and coupling is likely a response to changing rates of convergence or periodic flattening of the slab (Collins, 2002; Cawood and others, 2009; Cawood and 
others, 2011). Stress localization inboard of the east Australian margin in central Australia was related to the thermal and rheological properties of the crust (Raimondo and others, 2014). Given this overlap between plate margin and intraplate activity in eastern and central Australia respectively, as well as the timing of Kwangsian orogenesis post-dating final Gondwana assembly, we speculate that stress propagation from the East Gondwana convergent margin extended across Gondwana as far as South China and concentrated along the site of the pre-existing Nanhua Rift Basin (fig. 6B) and consequently resulted in basin inversion (fig. 6D). The overall longer history of intraplate orogenesis in central Australia versus South China suggests that initial stress localization was focused in South China but after 400 Ma only the central Australian region continued as a locus for intraplate activity.

The role of the Qinling orogenic belt in intraplate orogeny in South China is not clear at this stage, but given spatial and temporal relations it could have acted as a key backstop to the intraplate deformation system together with the cold, stable Yangtze Block.

CONCLUSIONS

The mid-Paleozoic Kwangsian Orogeny in the southeast part of South China is an intraplate orogenic event derived by the propagation of compressive stresses related to subduction of the Proto-Pacific Ocean along the margin of east Australia during the 460 to $400 \mathrm{Ma}$ period. The lithospheric architecture of pre-Kwangsian South China profoundly affected the localization of stresses, primarily inherited lithospheric discontinuities, thermal effects and fluid function. They contributed together in weakening the Cathaysian lithosphere beneath the Nanhua Basin, contrasting with the colder and more rigid Yangtze Block to the west. As a result, the stress sourced from subduction of the Proto-Pacific Ocean along the margin of east Australia was localized within the weakened Nanhua Basin and developed the intraplate Kwangsian Orogeny.

\section{ACKNOWLEDGMENTS}

This work was supported by the National Natural Science Foundation of China (Grant No. 41472086, 41272120), the fundamental Research Funds for the Central Universities, China University of Geosciences (Wuhan). The first author also acknowledges China Scholarship Council (Grant No. 201208420001) for supporting his research in the University of St Andrews. PAC acknowledges support from NERC grant NE/J021822/1. We thank Jianwei Zi, an anonymous reviewer, and Associate Editor Simon Wilde for comments that helped clarify our ideas and improve the manuscript. 
TABLE Al

The Kwangsian tectonothermal events in South China

\begin{tabular}{|c|c|c|c|c|c|}
\hline Location & $\begin{array}{c}\text { Tectonic } \\
\text { Unit }\end{array}$ & Lithology & Dating methods & Age (Ma) & References \\
\hline \multicolumn{6}{|c|}{ Granitic Magmatism } \\
\hline Gaozhou-Yunkai & Cathaysia & biotite orthogneiss & zircon $\mathrm{U}-\mathrm{Pb}$ & $427.1 \pm 4.2$ & Wang et al., 2007 \\
\hline Xinyi-Yunkai & Cathaysia & Granitic gneiss & zircon $\mathrm{U}-\mathrm{Pb}$ & $429.6 \pm 5.2$ & Wang et al., 2007 \\
\hline Bobai-Yunkai & Cathaysia & Granite & zircon $\mathrm{U}-\mathrm{Pb}$ & $440.7 \pm 5.6$ & Wang et al., 2007 \\
\hline Bobai-Yunkai & Cathaysia & Granitic gneiss & zircon $\mathrm{U}-\mathrm{Pb}$ & $421.9 \pm 9.8$ & Wang et al., 2007 \\
\hline Xingyi-Yunkai & Cathaysia & Orthogneiss & zircon $\mathrm{U}-\mathrm{Pb}$ & $450 \pm 8$ & Wang et al., 2011 \\
\hline Xinyi-Yunkai & Cathaysia & Gneissoid granite & zircon $\mathrm{U}-\mathrm{Pb}$ & $449 \pm 5$ & Wang et al., 2011 \\
\hline Rongxian-Yunkai & Cathaysia & Orthogneiss & zircon $\mathrm{U}-\mathrm{Pb}$ & $443 \pm 7$ & Wang et al., 2011 \\
\hline Beiliu-Yunkai & Cathaysia & Gneissoid granite & zircon $\mathrm{U}-\mathrm{Pb}$ & $415 \pm 7$ & Wang et al., 2011 \\
\hline Gaozhou-Yunkai & Cathaysia & Leucosome in migmatite & zircon U-Pb & $435 \pm 8$ & Wang et al., 2011 \\
\hline Gaozhou-Yunkai & Cathaysia & Orthogneiss & zircon $\mathrm{U}-\mathrm{Pb}$ & $452 \pm 6$ & Wang et al., 2011 \\
\hline Gaozhou-Yunkai & Cathaysia & charnockites & zircon $\mathrm{U}-\mathrm{Pb}$ & $432.5 \pm 3.2$ & Chen et al., 2012 \\
\hline Gaozhou-Yunkai & Cathaysia & orthogneisses & zircon $\mathrm{U}-\mathrm{Pb}$ & $433.3 \pm 3.2$ & Chen et al., 2012 \\
\hline Chishui-Yunkai & Cathaysia & granitoid & zircon $\mathrm{U}-\mathrm{Pb}$ & $436 \pm 3$ & Huang et al., 2013 \\
\hline Shamaoshi-Yunkai & Cathaysia & granitoid & zircon U-Pb & $436 \pm 3$ & Huang et al., 2013 \\
\hline Lianhuakeng-Yunkai & Cathaysia & granitoid & zircon $\mathrm{U}-\mathrm{Pb}$ & $436 \pm 4$ & Huang et al., 2013 \\
\hline Songnan-Yunkai & Cathaysia & granitoid & zircon $\mathrm{U}-\mathrm{Pb}$ & $436 \pm 6$ & Huang et al., 2013 \\
\hline Yunkai & Cathaysia & Gneissic granite & zircon $\mathrm{U}-\mathrm{Pb}$ & $430 \pm 10$ & Wan et al., 2010 \\
\hline Yunkai & Cathaysia & Gneissic granite & zircon U-Pb & $443 \pm 4$ & Wan et al., 2010 \\
\hline Yunkai & Cathaysia & Gneissic granite & zircon U-Pb & $437 \pm 5$ & Wan et al., 2010 \\
\hline Yichun-Wugong & Cathaysia & Gneissoid granite & zircon $\mathrm{U}-\mathrm{Pb}$ & $445 \pm 8$ & Wang et al., 2011 \\
\hline Yichun-Wugong & Cathaysia & Gneissoid granite & zircon U-Pb & $455 \pm 9$ & Wang et al., 2011 \\
\hline Anfu-Wugong & Cathaysia & Orthogneiss & zircon U-Pb & $456 \pm 5$ & Wang et al., 2011 \\
\hline Anfu-Wugong & Cathaysia & Orthogneiss & zircon $\mathrm{U}-\mathrm{Pb}$ & $443 \pm 5$ & Wang et al., 2011 \\
\hline Anfu-Wugong & Cathaysia & Gneissoid granite & zircon $\mathrm{U}-\mathrm{Pb}$ & $424 \pm 6$ & Wang et al., 2011 \\
\hline Yongfeng-Wugong & Cathaysia & Migmatite & zircon U-Pb & $452 \pm 4$ & Wang et al., 2011 \\
\hline Yihuang-Wuyi & Cathaysia & Gneissoid granite & zircon U-Pb & $410 \pm 10$ & Wang et al., 2011 \\
\hline Yeyang-Wuyi & Cathaysia & Orthogneiss & zircon $\mathrm{U}-\mathrm{Pb}$ & $427 \pm 15$ & Wang et al., 2011 \\
\hline Lishui-Wuyi & Cathaysia & Gneissoid granite & zircon $\mathrm{U}-\mathrm{Pb}$ & $430 \pm 9$ & Wang et al., 2011 \\
\hline Lichuang-Wuyi & Cathaysia & Leucosome in migmatite & zircon $\mathrm{U}-\mathrm{Pb}$ & $457 \pm 6$ & Wang et al., 2011 \\
\hline Wuping-Wuyi & Cathaysia & Gneissoid granite & zircon U-Pb & $430 \pm 6$ & Wang et al., 2011 \\
\hline Wuping-Wuyi & Cathaysia & Gneissoid granite & zircon U-Pb & $438 \pm 3$ & Wang et al., 2011 \\
\hline Yongping-Wuyi & Cathaysia & Gneissoid granite & zircon $\mathrm{U}-\mathrm{Pb}$ & $432 \pm 6$ & Wang et al., 2011 \\
\hline Yong'an-Wuyi & Cathaysia & Gneissoid granite & zircon $\mathrm{U}-\mathrm{Pb}$ & $427 \pm 4$ & Wang et al., 2011 \\
\hline Shanghang-Wuyi & Cathaysia & Orthogneiss & zircon $\mathrm{U}-\mathrm{Pb}$ & $426 \pm 6$ & Wang et al., 2011 \\
\hline Wuping-Wuyi & Cathaysia & Gneissoid granite & zircon $\mathrm{U}-\mathrm{Pb}$ & $426 \pm 8$ & Wang et al., 2011 \\
\hline Wuping-Wuyi & Cathaysia & Gneissoid granite & zircon U-Pb & $437 \pm 3$ & Wang et al., 2011 \\
\hline Wuping-Wuyi & Cathaysia & Orthogneiss & zircon $\mathrm{U}-\mathrm{Pb}$ & $430 \pm 6$ & Wang et al., 2011 \\
\hline Xinsi-Yunkai & Cathaysia & gneissoid granitic & zircon $\mathrm{U}-\mathrm{Pb}$ & $466 \pm 4$ & Wang YJ et al., 2013c \\
\hline Longhugang-Yunkai & Cathaysia & gneissoid granitic & zircon $\mathrm{U}-\mathrm{Pb}$ & $442 \pm 3$ & Wang YJ et al., $2013 \mathrm{c}$ \\
\hline Chencai-N Wuyi & Cathaysia & Migmatite & zircon U-Pb & $433 \pm 3$ & Li et al., 2010 \\
\hline Chencai-N Wuyi & Cathaysia & Gneissic granite & zircon U-Pb & $435 \pm 4$ & Li et al., 2010 \\
\hline Wuyi & Cathaysia & Granitic vein & zircon $\mathrm{U}-\mathrm{Pb}$ & $452 \pm 8$ & Li et al., 2010 \\
\hline Wuyi & Cathaysia & Granite & zircon $\mathrm{U}-\mathrm{Pb}$ & $432 \pm 3$ & Li et al., 2010 \\
\hline Wuyi & Cathaysia & Granite & zircon U-Pb & $433 \pm 5$ & Li et al., 2010 \\
\hline Fujian & Cathaysia & Leucosome in Migmatite & zircon $\mathrm{U}-\mathrm{Pb}$ & $439 \pm 6$ & Liu R. et al., 2010 \\
\hline Fujian & Cathaysia & Leucosome in Migmatite & zircon U-Pb & $439 \pm 4$ & Liu R. et al., 2010 \\
\hline Fujian & Cathaysia & Granite & zircon $\mathrm{U}-\mathrm{Pb}$ & $438 \pm 5$ & Liu R. et al., 2010 \\
\hline Fujian & Cathaysia & Granite & zircon U-Pb & $442 \pm 4$ & Liu R. et al., 2010 \\
\hline Wuyishan(Doushui) & Cathaysia & Granite & zircon U-Pb & $424 \pm 5$ & Shu et al., 2014 \\
\hline Nanling(Lichuan) & Cathaysia & Granite & zircon U-Pb & $435 \pm 4$ & Shu et al., 2014 \\
\hline Nanling(Hengyang) & Cathaysia & Granite & zircon $\mathrm{U}-\mathrm{Pb}$ & $428 \pm 3$ & Shu et al., 2014 \\
\hline Nanling(Zhenzhu) & Cathaysia & Granite & zircon $\mathrm{U}-\mathrm{Pb}$ & $427 \pm 2$ & Shu et al., 2014 \\
\hline Wuyishan(Xiawan) & Cathaysia & Granite & zircon $\mathrm{U}-\mathrm{Pb}$ & $413 \pm 3$ & Xia et al., 2014 \\
\hline Wuyishan(Xiawan) & Cathaysia & Granite & zircon U-Pb & $436 \pm 6$ & Xia et al., 2014 \\
\hline Wuyishan(Duntou) & Cathaysia & Granite & zircon $\mathrm{U}-\mathrm{Pb}$ & $409 \pm 3$ & Xia et al., 2014 \\
\hline Wuyishan(Duntou) & Cathaysia & Granite & zircon U-Pb & $411 \pm 4$ & Xia et al., 2014 \\
\hline Wuyishan(Duntou) & Cathaysia & Granite & zircon $\mathrm{U}-\mathrm{Pb}$ & $436 \pm 5$ & Xia et al., 2014 \\
\hline Wuyishan(Duntou) & Cathaysia & Granite & zircon $\mathrm{U}-\mathrm{Pb}$ & $411 \pm 4$ & Xia et al., 2014 \\
\hline Wuyishan(Qingliu) & Cathaysia & Gneissic Granite & zircon $\mathrm{U}-\mathrm{Pb}$ & $436 \pm 6$ & Xu X.B. et al., 2011 \\
\hline Wuyishan(Taoxi) & Cathaysia & Gneissic Granite & zircon $\mathrm{U}-\mathrm{Pb}$ & $431 \pm 3$ & Xu X.B. et al., 2011 \\
\hline Wuyishan(Taoxi) & Cathaysia & Gneissic Granite & zircon U-Pb & $441 \pm 5$ & Xu X.B. et al., 2011 \\
\hline Wuyishan(Weipu) & Cathaysia & Granite & zircon U-Pb & $447 \pm 5$ & Xu X.B., et al., 2009 \\
\hline Wuyishan(Weipu) & Cathaysia & Granite & zircon U-Pb & $441 \pm 3$ & Xu X.B., et al., 2009 \\
\hline Wuyishan(Weipu) & Cathaysia & Gneissic granite & zircon U-Pb & $436 \pm 3$ & Xu X.B. et al., 2011 \\
\hline Wuyishan(Luofu) & Cathaysia & Granite & zircon $\mathrm{U}-\mathrm{Pb}$ & $446 \pm 4$ & Xu X.B., et al., 2009 \\
\hline Wuyishan(Wuping) & Cathaysia & Granite & zircon $\mathrm{U}-\mathrm{Pb}$ & $441 \pm 5$ & Xu X.B. et al., 2011 \\
\hline Wuyishan(Wuping) & Cathaysia & Granite & zircon $\mathrm{U}-\mathrm{Pb}$ & $431 \pm 3$ & Xu X.B. et al., 2011 \\
\hline Wuyishan(Tianjingping Complex) & Cathaysia & granodioritic neosomes of migmatites & zircon $\mathrm{U}-\mathrm{Pb}$ & $447 \pm 2$ & Zeng et al., 2008 \\
\hline Yunkai & Cathaysia & Granite & zircon $\mathrm{U}-\mathrm{Pb}$ & $443 \pm 2$ & Wang L, et al., 2013b \\
\hline Yunkai & Cathaysia & Granite & zircon $\mathrm{U}-\mathrm{Pb}$ & $446 \pm 2$ & Wang L, et al., 2013b \\
\hline Yunkai & Cathaysia & Granite & zircon $\mathrm{U}-\mathrm{Pb}$ & $441 \pm 2$ & Wang L, et al., 2013b \\
\hline Yunkai & Cathaysia & Granite & zircon $\mathrm{U}-\mathrm{Pb}$ & $444 \pm 2$ & Wang L, et al., 2013b \\
\hline Guangxi & Cathaysia & Granite & zircon $\mathrm{U}-\mathrm{Pb}$ & $412 \pm 2$ & Wang Y.L. et al., 2011 \\
\hline Guangxi & Cathaysia & Granite & zircon $\mathrm{U}-\mathrm{Pb}$ & $435 \pm 2$ & Wang Y.L. et al., 2011 \\
\hline Guangxi & Cathaysia & Granite & zircon U-Pb & $442 \pm 2$ & Wang Y.L. et al., 2011 \\
\hline Wuyishan(Weipu) & Cathaysia & Granite & zircon $\mathrm{U}-\mathrm{Pb}$ & $430 \pm 3$ & Zhang A.M. et al., 2010a \\
\hline
\end{tabular}


TABLE A1

(continued)

\begin{tabular}{|c|c|c|c|c|c|}
\hline Location & $\begin{array}{c}\text { Tectonic } \\
\text { Unit }\end{array}$ & Lithology & Dating methods & Age (Ma) & References \\
\hline \multicolumn{6}{|c|}{ Granitic Magmatism } \\
\hline Wuyishan(Weipu) & Cathaysia & Granite & zircon $\mathrm{U}-\mathrm{Pb}$ & $446 \pm 4$ & Zhang A.M. et al., 2010a \\
\hline Wuyishan(Ninghua) & Cathaysia & Granite & zircon $\mathrm{U}-\mathrm{Pb}$ & $448 \pm 3$ & Zhang A.M. et al., 2010a \\
\hline Hunan(Banshanpu) & SE Yangtze & Granite & zircon $\mathrm{U}-\mathrm{Pb}$ & $418 \pm 2$ & Zhang A.M. et al., 2010a \\
\hline Hunan(Banshanpu) & SE Yangtze & I-type Granite & zircon $\mathrm{U}-\mathrm{Pb}$ & $432 \pm 3$ & Guan et al., 2014 \\
\hline Hunan(Hongxiaqiao) & SE Yangtze & Granite & zircon $\mathrm{U}-\mathrm{Pb}$ & $432 \pm 6$ & Zhang F.F. et al., 2010b \\
\hline Hunan(Hongxiaqiao) & SE Yangtze & I-type Granite & zircon $\mathrm{U}-\mathrm{Pb}$ & $434 \pm 3$ & Guan et al., 2014 \\
\hline Hunan(Miaoershan) & SE Yangtze & Granite & zircon $\mathrm{U}-\mathrm{Pb}$ & $400 \pm 4$ & Zhang FF et al., 2012 \\
\hline Hunan(Miaoershan) & SE Yangtze & Granite & zircon $\mathrm{U}-\mathrm{Pb}$ & $415 \pm 2$ & Zhang FF et al., 2012 \\
\hline Hunan(Miaoershan) & SE Yangtze & Granite & zircon U-Pb & $435 \pm 4$ & Zhao KD et al., 2013 \\
\hline Hunan(Miaoershan) & SE Yangtze & Granite & zircon $\mathrm{U}-\mathrm{Pb}$ & $427 \pm 3$ & Zhao KD et al., 2013 \\
\hline Hunan(Miaoershan) & SE Yangtze & Granite & zircon $\mathrm{U}-\mathrm{Pb}$ & $417 \pm 6$ & Zhao KD et al., 2013 \\
\hline Hunan(Miaoershan) & SE Yangtze & Granite & zircon $\mathrm{U}-\mathrm{Pb}$ & $404 \pm 6$ & Zhao KD et al., 2013 \\
\hline Hunan(Miaoershan) & SE Yangtze & Granite & zircon $\mathrm{U}-\mathrm{Pb}$ & $382 \pm 2$ & Zhao KD et al., 2013 \\
\hline Hunan(Haiyangshan) & SE Yangtze & Granite & zircon U-Pb & $429 \pm 11$ & Zhang F.F. et al., 2012 \\
\hline Hunan(Penggongmiao) & Cathaysia & Granite & zircon $\mathrm{U}-\mathrm{Pb}$ & $405 \pm 3$ & Zhang F.F. et al., 2012 \\
\hline Hunan(Penggongmiao) & Cathaysia & Granite & zircon $\mathrm{U}-\mathrm{Pb}$ & $435 \pm 3$ & Zhang W.L. et al., 2011a \\
\hline Hunan(Penggongmiao) & Cathaysia & Granite & zircon U-Pb & $436 \pm 3$ & Zhang W.L. et al., 2011a \\
\hline Hunan(Penggongmiao) & Cathaysia & Granite & zircon U-Pb & $427 \pm 3$ & Zhang W.L. et al., 2011a \\
\hline Jiangxi(Zhangjiafang) & SE Yangtze & Granite & zircon $\mathrm{U}-\mathrm{Pb}$ & $440 \pm 2$ & Zhang F.F. et al., 2010 \\
\hline Jiangxi(Fengdingshan) & SE Yangtze & Granite & zircon $\mathrm{U}-\mathrm{Pb}$ & $402 \pm 2$ & Zhang F.F. et al., 2010 \\
\hline Jiangxi(Fengdingshan) & SE Yangtze & I-type Granite & zircon $\mathrm{U}-\mathrm{Pb}$ & $436 \pm 5$ & Zhong Y.F. et al., 2013 \\
\hline Jiangxi(Shanzhuang) & Cathaysia & Granite & zircon $\mathrm{U}-\mathrm{Pb}$ & $424 \pm 3$ & Zhang F.F. et al., 2010 \\
\hline Jiangxi(Shanzhuang) & Cathaysia & Granite & zircon $\mathrm{U}-\mathrm{Pb}$ & $441 \pm 3$ & Zhang F.F. et al., 2012 \\
\hline Jiangxi(Le'an) & Cathaysia & Granite & zircon $\mathrm{U}-\mathrm{Pb}$ & $429 \pm 2$ & Zhang F.F. et al., 2012 \\
\hline Jiangxi(Wanyangshan) & Cathaysia & Granite & zircon $\mathrm{U}-\mathrm{Pb}$ & $433 \pm 4$ & Zhang F.F. et al., 2012 \\
\hline Jiangxi(Tanghu) & Cathaysia & Granite & zircon $\mathrm{U}-\mathrm{Pb}$ & $454 \pm 2$ & Zhang F.F. et al., 2012 \\
\hline Jiangxi(Guixi)) & Cathaysia & Granite & zircon U-Pb & $436 \pm 6$ & Zhang Y., et al., $2011 \mathrm{~b}$ \\
\hline Jiangxi(Yihuangljiekou) & Cathaysia & Granite & zircon U-Pb & $441 \pm 4$ & Zhang Y., et al., 2011b \\
\hline Jiangxi(Lichuan) & Cathaysia & Granite & zircon $\mathrm{U}-\mathrm{Pb}$ & $436 \pm 6$ & Zhang Y., et al., 2011b \\
\hline Jiangxi(Jinxi) & Cathaysia & Granite & zircon $\mathrm{U}-\mathrm{Pb}$ & $442 \pm 3$ & Zhang Y., et al., 2011b \\
\hline Wuyishan(Jiangxi, Huitong) & Cathaysia & A-type Granite & zircon $\mathrm{U}-\mathrm{Pb}$ & $415 \pm 3$ & Feng et al., 2014 \\
\hline Wuyishan(Jiangxi, Epo) & Cathaysia & A-type Granite & zircon $\mathrm{U}-\mathrm{Pb}$ & $414 \pm 3$ & Feng et al., 2014 \\
\hline Wuyishan(Jiangxi, Epo) & Cathaysia & A-type Granite & zircon $\mathrm{U}-\mathrm{Pb}$ & $413 \pm 2$ & Feng et al., 2014 \\
\hline Baiyunshan-Nanling & Cathaysia & Granite & zircon U-Pb & $454 \pm 8$ & Yang et al., 2010 \\
\hline Yunkai-Gaozhou & Cathaysia & Charnockite & zircon U-Pb & $439 \pm 2$ & Wang D et al., 2013a \\
\hline Yunkai-Gaozhou & Cathaysia & Charnockite & zircon U-Pb & $439 \pm 4$ & Wang D et al., 2013a \\
\hline Yunkai-Gaozhou & Cathaysia & Gneissic migmatite & zircon $\mathrm{U}-\mathrm{Pb}$ & $437 \pm 4$ & Wang D et al., 2013a \\
\hline Yunkai-Gaozhou & Cathaysia & Gneissic migmatite & zircon $\mathrm{U}-\mathrm{Pb}$ & $438 \pm 4$ & Wang D et al., 2013a \\
\hline Yunkai-Gaozhou & Cathaysia & Bt-Pl gneiss & zircon $\mathrm{U}-\mathrm{Pb}$ & $425 \pm 5$ & Wang D et al., 2013a \\
\hline Yunkai-Gaozhou & Cathaysia & Bt-Pl gneiss & zircon $\mathrm{U}-\mathrm{Pb}$ & $432 \pm 3$ & Wang D et al., 2013a \\
\hline Nanling-Niutangjie & Cathaysia & Granite & zircon $\mathrm{U}-\mathrm{Pb}$ & $422 \pm 2$ & Yang Z., et al., 2014 \\
\hline $\begin{array}{l}\text { Fengwan between Yunka and } \\
\text { Wuyishan }\end{array}$ & Cathaysia & $\begin{array}{l}\text { Mid-basic Magmatism } \\
\text { andesitic }\end{array}$ & zircon U-Pb & $435 \pm 6$ & Yao W.H., et al., 2012 \\
\hline $\begin{array}{l}\text { Fengwan between Yunka and } \\
\text { Wuyishan }\end{array}$ & Cathaysia & dacitic & zircon $\mathrm{U}-\mathrm{Pb}$ & $435 \pm 6$ & Yao W.H., et al., 2012 \\
\hline Taoyuan & SE Yangtze & hornblende gabbro & zircon $\mathrm{U}-\mathrm{Pb}$ & $409 \pm 2$ & Zhong et al., 2014 \\
\hline Longhugang-Yunkai & Cathaysia & gabbro & zircon $\mathrm{U}-\mathrm{Pb}$ & $423 \pm 8$ & Wang Y.J., et al., 2013c \\
\hline Xinchuan-Nanling & Cathaysia & gabbro & zircon $\mathrm{U}-\mathrm{Pb}$ & $434 \pm 5$ & Wang Y.J., et al., 2013c \\
\hline Xinsi-Nanling & Cathaysia & gabbro & zircon $\mathrm{U}-\mathrm{Pb}$ & $420 \pm 3$ & Wang Y.J., et al., 2013c \\
\hline \multicolumn{6}{|c|}{ Metamorphic Event } \\
\hline Qinyuan-Wugongshan & Cathaysia & Plagioclase amphibolite & Zircon U-Pb & $450 \pm 4$ & Wang Y.J. et al., 2012 \\
\hline Zhuji-Wuyishan & Cathaysia & Plagioclase amphibolite & Zircon U-Pb & $428 \pm 9$ & Wang Y.J. et al., 2012 \\
\hline Jianning-Wuyishan & Cathaysia & Plagioclase amphibolite & Zircon U-Pb & $468 \pm 4$ & Wang Y.J. et al., 2012 \\
\hline Jianning-Wuyishan & Cathaysia & Migmatized amphibolite & Zircon U-Pb & $435 \pm 6$ & Wang Y.J. et al., 2012 \\
\hline Yiyang-Wugongshan & Cathaysia & Plagioclase amphibolite & Zircon U-Pb & $429 \pm 5$ & Wang Y.J. et al., 2012 \\
\hline Zhuji-N Wuyishan & Cathaysia & amphibolites & Zircon U-Pb & $428 \pm 9$ & Wang Y.J. et al., 2012 \\
\hline Gaozhou-Yunkai & Cathaysia & Garnet-bearing amphibolite & Zircon U-Pb & $446 \pm 12$ & Wang Y.J. et al., 2012 \\
\hline Gaozhou-Yunkai & Cathaysia & Pelitic granulite & Zircon U-Pb & $428 \pm 18$ & Wang Y.J. et al., 2012 \\
\hline Taoxi-Wuyishan & Cathaysia & migmatite & Zircon U-Pb & $496 \pm 4$ & Zhang A.M. et al., 2011 \\
\hline Taoxi-Wuyishan & Cathaysia & monzonitic granite & Zircon U-Pb & $443 \pm 10$ & Yu et al., 2005 \\
\hline Taoxi-Wuyishan & Cathaysia & monzonitic granite & Zircon U-Pb & $478.7 \pm 5.4$ & Yu et al., 2005 \\
\hline Wuyishan & Cathaysia & granulite & Zircon U-Pb & $435.5 \pm 3.5$ & Yu et al., 2014 \\
\hline Chencai-N Wuyi & Cathaysia & Meta-gabbro & Zircon U-Pb & $454 \pm 29$ & Li et al., 2010 \\
\hline Chencai-N Wuyi & Cathaysia & Metapelite & Zircon U-Pb & $447 \pm 7$ & Li et al., 2010 \\
\hline Chencai-N Wuyi & Cathaysia & Granitic gneiss & Zircon U-Pb & $460 \pm 10$ & Li et al., 2010 \\
\hline Wuyishan & Cathaysia & Amphibolite & Zircon U-Pb & $443 \pm 6$ & Li et al., 2010 \\
\hline Wuyishan & Cathaysia & Gneiss & Zircon U-Pb & $458 \pm 6$ & Wan et al., 2007 \\
\hline Fujian-Wuyishan & Cathaysia & mesosome in Migmatite & Zircon $\mathrm{U}-\mathrm{Pb}$ & $453 \pm 3$ & Liu R., et al., 2010 \\
\hline Fujian-Wuyishan & Cathaysia & mesosome in Migmatite & Zircon U-Pb & $442 \pm 8$ & Liu R., et al., 2010 \\
\hline Wuyishan(Taoxi) & Cathaysia & ultramylonite & zircon $\mathrm{U}-\mathrm{Pb}$ & $434 \pm 7$ & Xu X.B. et al., 2011 \\
\hline Yunkai & Cathaysia & two-mica gneiss & zircon U-Pb & $443 \pm 9$ & Wan et al., 2010 \\
\hline Yunkai & Cathaysia & biotite gneiss & zircon $\mathrm{U}-\mathrm{Pb}$ & $438 \pm 8$ & Wan et al., 2010 \\
\hline Wuyishan & Cathaysia & Schist & EMP monazite & $443 \pm 11$ & Chen et al., 2008 \\
\hline Gaozhou-Yunkai & Cathaysia & Garnet-cordierite granulite & EMP monazite & $432 \pm 12$ & Chen et al., 2012 \\
\hline Gaozhou-Yunkai & Cathaysia & Garnet-cordierite granulite & EMP monazite & $433 \pm 10$ & Chen et al., 2012 \\
\hline
\end{tabular}


TABLE A1

(continued)

\begin{tabular}{|c|c|c|c|c|c|}
\hline Location & $\begin{array}{c}\text { Tectonic } \\
\text { Unit } \\
\end{array}$ & Lithology & Dating methods & Age (Ma) & References \\
\hline Gaozhou-Yunkai & Cathaysia & $\begin{array}{l}\text { Metamorphic Event } \\
\text { Garnet-cordierite granulite }\end{array}$ & EMP monazite & $441 \pm 17$ & Chen et al., 2012 \\
\hline Gaozhou-Yunkai & Cathaysia & Orthopyroxene-biotite granulite & EMP monazite & $439 \pm 11$ & Chen et al., 2012 \\
\hline Gaozhou-Yunkai & Cathaysia & Orthopyroxene-biotite granulite & EMP monazite & $432 \pm 21$ & Chen et al., 2012 \\
\hline Wuyishan & Cathaysia & Two-micas granite & EMP monazite & $437 \pm 5$ & Charvet et al., 2010 \\
\hline Wuyishan & Cathaysia & Gneiss & EMP monazite & $433 \pm 9$ & Charvet et al., 2010 \\
\hline Wuyishan & Cathaysia & Two-micas granite & EMP monazite & $412 \pm 5$ & Charvet et al., 2010 \\
\hline Wuyishan & Cathaysia & Micaschist & EMP monazite & $453 \pm 7$ & Faure et al., 2009 \\
\hline Wuyishan-Zhenghe-Dapu Fault & Cathaysia & Marble & ${ }^{40} \mathrm{Ar}{ }^{39} \mathrm{Ar}$ muscovite & $391 \pm 3$ & Shu L.S., et al., 1999 \\
\hline Wuyishan & Cathaysia & Mylonite & ${ }^{40} \mathrm{Ar} /{ }^{39} \mathrm{Ar}$ biotite & $433 \pm 3$ & Shu L.S., et al., 2008 \\
\hline Wuyishan & Cathaysia & Mylonite & ${ }^{40} \mathrm{Ar} /{ }^{39} \mathrm{Ar}$ biotite & $430 \pm 2$ & Shu L.S., et al., 2008 \\
\hline Wuyishan-Jiangshan Fault & Cathaysia & Mylonite & ${ }^{40} \mathrm{Ar} /{ }^{39} \mathrm{Ar}$ biotite & $421 \pm 8$ & Shu L.S., et al., 2008 \\
\hline Wuyishan-Jiangshan Fault & Cathaysia & Mylonite & ${ }^{40} \mathrm{Ar} /{ }^{39}$ Ar biotite & $428 \pm 2$ & Shu L.S., et al., 2008 \\
\hline Chencai-N Wuyi & Cathaysia & Meta-gabbro & ${ }^{40} \mathrm{Ar} /{ }^{39} \mathrm{Ar}$ hornblende & $426 \pm 2$ & Li et al., 2010 \\
\hline Chencai-N Wuyi & Cathaysia & Metapelite & ${ }^{40} \mathrm{Ar} /{ }^{39} \mathrm{Ar}$ biotite cores & $425 \pm 7$ & Li et al., 2010 \\
\hline Wuyishan & Cathaysia & Mica schist & ${ }^{40} \mathrm{Ar} /{ }^{39} \mathrm{Ar}$ white mica & $438 \pm 8$ & Li et al., 2010 \\
\hline Wuyishan & Cathaysia & Mica schist & ${ }^{40} \mathrm{Ar} /{ }^{39} \mathrm{Ar}$ white mica & $420 \pm 3$ & Li et al., 2010 \\
\hline Wuyishan & Cathaysia & Micaschist & ${ }^{40} \mathrm{Ar} /{ }^{39} \mathrm{Ar}$ muscovite & $405 \pm 4$ & Faure et al., 2009 \\
\hline Wuyishan & Cathaysia & Micaschist & ${ }^{40} \mathrm{Ar} /{ }^{39}$ Ar biotite & $397 \pm 4$ & Faure et al., 2009 \\
\hline
\end{tabular}

\section{Appendix A2}

TABLE A2

$U-P b$ data for detrital zircons from the: Cambrian in South China, the Ordovician in South China, the Silurian in the Yangzte of South China, the Devonian in South China, the Cambrian in Sanya, Hainan Island, the Precambiran in

Hainan Island, and the Ordovician in Sanya, Hainan Island

http:/ / earth.geology.yale.edu/\% 7eajs/SupplementaryData/2016/Xu/TableA2.xls

APpendix A3

TABLE A3

$U-P b$ data for detrital zircons from the Cambrian-Ordovician along the northern margin of Indian Himalaya http:/ / earth.geology.yale.edu/\% 7eajs/SupplementaryData/2016/Xu/TableA3.xls

Appendix A4

TABLE A4

U-Pb data for detrital zircons from the Northampton Complex, Western Australia http:/ / earth.geology.yale.edu/\% 7eajs/SupplementaryData/2016/Xu/TableA4.xls 
APPENDix A5

TABLe A5

The tectonothermal events along the northern margin of east Gondwana

\begin{tabular}{|c|c|c|c|c|c|}
\hline Location & Tectonic Unit & Lithology & Dating methods & Age (Ma) & References \\
\hline \multicolumn{6}{|c|}{ "Granitic magmatism } \\
\hline Mandu Khola & Greater Himalaya & Granite & zircon U-Pb & $473 \pm 6$ & Gehrels et al., 2006a \\
\hline Bhimphedi & Greater Himalaya & Granite & zircon U-Pb & $476 \pm 3$ & Gehrels et al., 2006a \\
\hline Agra & Greater Himalaya & Granite & zircon U-Pb & $480 \pm 4$ & Gehrels et al., 2006a \\
\hline Mandu Khola & Greater Himalaya & Granite & zircon U-Pb & $484 \pm 5$ & Gehrels et al., 2006a \\
\hline Ruwa & Greater Himalaya & Granite & zircon U-Pb & $474 \pm 3$ & Gehrels et al., 2006b \\
\hline Ruwa & Greater Himalaya & Granite & zircon U-Pb & $484 \pm 2$ & Gehrels et al., 2006b \\
\hline Kala & Greater Himalaya & Granite & zircon U-Pb & $512 \pm 5$ & Gehrels et al., 2006b \\
\hline Simchar & Greater Himalaya & Granite & zircon U-Pb & $471 \pm 10$ & Johnson et al., 2001 \\
\hline Dadeldhura & Greater Himalaya & Granite & zircon U-Pb & $478 \pm 4$ & DeCelles et al., 2000 \\
\hline Kharta & Greater Himalaya & Granite & zircon $\mathrm{U}-\mathrm{Pb}$ & $493 \pm 10$ & Liu et al., 2007 \\
\hline Kathmandu & Greater Himalaya & Granite & zircon U-Pb & $476.9 \pm 4.2$ & Cawood et al., 2007 \\
\hline Kathmandu & Greater Himalaya & Granite & zircon $\mathrm{U}-\mathrm{Pb}$ & $478 \pm 17$ & Cawood et al., 2007 \\
\hline Diannian & Greater Himalaya & Orthogneiss & zircon U-Pb & $496 \pm 1.1$ & Zhang $\mathrm{Z} \mathrm{M}$ et al., 2012 \\
\hline Gega & Greater Himalaya & Orthogneiss & zircon U-Pb & $495 \pm 5.3$ & Zhang $Z \mathrm{M}$ et al., 2012 \\
\hline $\mathrm{Pai}$ & Greater Himalaya & Orthogneiss & zircon U-Pb & $490 \pm 11$ & Zhang $\mathrm{Z} \mathrm{M}$ et al., 2012 \\
\hline Diannian & Greater Himalaya & Orthogneiss & zircon $\mathrm{U}-\mathrm{Pb}$ & $502 \pm 9.4$ & Zhang $\mathrm{Z} \mathrm{M}$ et al., 2012 \\
\hline Hapoli & Greater Himalaya & Orthogneiss & zircon $\mathrm{U}-\mathrm{Pb}$ & $504.9 \pm 8.3$ & Yin et al., 2010 \\
\hline Hapoli & Greater Himalaya & augen gneiss & zircon U-Pb & $512 \pm 14$ & Yin et al., 2010 \\
\hline Mabja & Tethyan Himalaya & Granitic gneiss & zircon U-Pb & $503 \pm 18$ & Lee and White, 2007 \\
\hline Mabja & Tethyan Himalaya & Granitic gneiss & zircon U-Pb & $491 \pm 15$ & Lee and White, 2007 \\
\hline Mabja & Tethyan Himalaya & Granitic gneiss & zircon $\mathrm{U}-\mathrm{Pb}$ & $484 \pm 8$ & Lee and White, 2007 \\
\hline Kangmar & Tethyan Himalaya & Granitic gneiss & zircon U-Pb & $508 \pm 1$ & Lee et al., 2000 \\
\hline Gyirong & Tethyan Himalaya & Granitic gneiss & zircon U-Pb & $473.5 \pm 1.5$ & Wang X X et al., 2012 \\
\hline Gyirong & Tethyan Himalaya & Granitic gneiss & zircon $\mathrm{U}-\mathrm{Pb}$ & $475.5 \pm 1.1$ & Wang X X et al., 2012 \\
\hline Gyirong & Tethyan Himalaya & Granitic gneiss & zircon U-Pb & $484.7 \pm 1.4$ & Wang X X et al., 2012 \\
\hline Gyirong & Tethyan Himalaya & Granitic gneiss & zircon U-Pb & $485.8 \pm 1.7$ & Wang X X et al., 2012 \\
\hline Kangmar & Tethyan Himalaya & Granitic gneiss & zircon U-Pb & $478.3 \pm 3.1$ & Wang X X et al., 2012 \\
\hline Kangmar & Tethyan Himalaya & Granitic gneiss & zircon U-Pb & $484.0 \pm 2.9$ & Wang X X et al., 2012 \\
\hline Kangmar & Tethyan Himalaya & Granitic gneiss & zircon U-Pb & $494.8 \pm 1.2$ & Wang X X et al., 2012 \\
\hline Kangmar & Tethyan Himalaya & Granitic gneiss & zircon U-Pb & $499.4 \pm 1.2$ & Wang X X et al., 2012 \\
\hline Yalashangbo & Tethyan Himalaya & Granitic gneiss & zircon U-Pb & $488.0 \pm 1.0$ & Wang X X et al., 2012 \\
\hline Yalashangbo & Tethyan Himalaya & Granitic gneiss & zircon U-Pb & $495.9 \pm 1.2$ & Wang X X et al., 2012 \\
\hline Duguer Range & Southern Qiangtang & orthogneisses & zircon U-Pb & $476 \pm 5$ & Pullen et al., 2011 \\
\hline Duguer Range & Southern Qiangtang & orthogneisses & zircon U-Pb & $475 \pm 5$ & Pullen et al., 2011 \\
\hline Duguer Range & Southern Qiangtang & orthogneisses & zircon $\mathrm{U}-\mathrm{Pb}$ & $474 \pm 5$ & Pullen et al., 2011 \\
\hline Duguer Range & Southern Qiangtang & orthogneisses & zircon U-Pb & $474 \pm 5$ & Pullen et al., 2011 \\
\hline Duguer Range & Southern Qiangtang & orthogneisses & zircon U-Pb & $474 \pm 4$ & Pullen et al., 2011 \\
\hline Amdo & Amdo & Granite gneiss & zircon U-Pb & $468 \pm 53$ & Guynn et al., 2012 \\
\hline Amdo & Amdo & Granite gneiss & zircon U-Pb & $532 \pm 7$ & Guynn et al., 2012 \\
\hline Amdo & Amdo & Granodiorite gneiss & zircon $\mathrm{U}-\mathrm{Pb}$ & $483 \pm 13$ & Guynn et al., 2012 \\
\hline Amdo & Amdo & Granite gneiss & zircon U-Pb & $498 \pm 11$ & Guynn et al., 2012 \\
\hline Amdo & Amdo & Granite gneiss & zircon U-Pb & $487 \pm 16$ & Guynn et al., 2012 \\
\hline Hua Hin & Sibumasu & orthogneiss & zircon U-Pb & $501.5 \pm 7.5$ & Lin et al., 2013 \\
\hline Gaoligong (Tengchong) & Sibumasu & Gneissic granite & zircon U-Pb & $487 \pm 11$ & Song et al., 2007 \\
\hline Mengnuo & Sibumasu & Monzogranite & zircon $\mathrm{U}-\mathrm{Pb}$ & $498.5 \pm 4.6$ & Liu et al., 2009 \\
\hline Mengnuo & Sibumasu & Monzogranite & zircon U-Pb & $502 \pm 4.7$ & Liu et al., 2009 \\
\hline Longlin & Sibumasu & Monzogranite & zircon U-Pb & $500.1 \pm 4.1$ & Liu et al., 2009 \\
\hline Dahaoping, Tengchong & Sibumasu & Leucogranite & zircon U-Pb & $492 \pm 5$ & Wang Y J et al., 2013 \\
\hline Dahaoping, Tengchong & Sibumasu & Mylonitic granite & zircon U-Pb & $488 \pm 6$ & Wang Y J et al., 2013 \\
\hline West Dahaoping & Sibumasu & Gneissoid granite & zircon $\mathrm{U}-\mathrm{Pb}$ & $484 \pm 6$ & Wang Y J et al., 2013 \\
\hline West Dahaoping & Sibumasu & Gneissoid granite & zircon U-Pb & $488 \pm 5$ & Wang Y J et al., 2013 \\
\hline West Dahaoping & Sibumasu & Leucogranite & zircon U-Pb & $485 \pm 7$ & Wang Y J et al., 2013 \\
\hline West Dahaoping & Sibumasu & Leucogranite & zircon U-Pb & $491 \pm 9$ & Wang Y J et al., 2013 \\
\hline Mengmao, Longlin & Sibumasu & monogranite & zircon U-Pb & $473 \pm 6$ & Wang Y J et al., 2013 \\
\hline Xiangda, Longlin & Sibumasu & monogranite & zircon U-Pb & $473 \pm 5$ & Wang Y J et al., 2013 \\
\hline West Pingda & Sibumasu & monogranite & zircon U-Pb & $472 \pm 5$ & Wang Y J et al., 2013 \\
\hline Lisuo, Ximeng & Sibumasu & Leucogranite & zircon U-Pb & $463 \pm 3$ & Wang Y J et al., 2013 \\
\hline Manghen, Ximeng & Sibumasu & Gneissoid granite & zircon U-Pb & $460 \pm 6$ & Wang Y J et al., 2013 \\
\hline East Manghen, Ximeng & Sibumasu & Leucogranite & zircon U-Pb & $462 \pm 5$ & Wang Y J et al., 2013 \\
\hline Dak To-Kontum Massif & Indochina & Granodiorite & zircon U-Pb & $451.2 \pm 2.6$ & Nagy et al., 2001 \\
\hline Song Chay & Indochina & two-micas granite & zircon U-Pb & $428 \pm 5$ & Roger et al., 2000 \\
\hline
\end{tabular}


TABLE A5

(continued)

\begin{tabular}{|c|c|c|c|c|c|}
\hline Location & Tectonic Unit & Lithology & Dating methods & Age (Ma) & References \\
\hline \multicolumn{6}{|c|}{ Metamorphic ages } \\
\hline Kalitar & Greater Himalaya & schist & $\begin{array}{l}\text { Th- } \mathrm{Pb} \text { ages of } \\
\text { monazite inclusions } \\
\text { in garnet crystals }\end{array}$ & $490 \pm 22$ & Gehrels et al., 2006a \\
\hline Namche & Greater Himalaya & Migmatite Orthogneiss & $\begin{array}{l}\text { Th- } \mathrm{Pb} \text { ages of } \\
\text { monazite inclusions } \\
\text { in garnet crystals }\end{array}$ & $548 \pm 17$ & Catlos et al., 2002 \\
\hline Barun & Greater Himalaya & Gneiss & $\begin{array}{l}\text { Th- } \mathrm{Pb} \text { ages of } \\
\text { monazite inclusions } \\
\text { in garnet crystals }\end{array}$ & $436 \pm 8$ & Catlos et al., 2002 \\
\hline Namche Barwa & Greater Himalaya & Diopsidite & Zircon U-Pb & $505.2 \pm 3.1$ & Zhang Z. M., et al., 2008 \\
\hline Song Bien & Indochina & $\begin{array}{c}\text { leucosome of anatexites in } \\
\text { granulites }\end{array}$ & monazite $\mathrm{U}-\mathrm{Pb}$ ages & $465 \pm 1$ & Roger et al., 2007 \\
\hline Kham Duc & Indochina & Gneiss & Zircon U-Pb & $447 \pm 6$ & Usuki et al., 2009 \\
\hline Kham Duc & Indochina & Gneiss & Zircon U-Pb & $452 \pm 6$ & Usuki et al., 2009 \\
\hline
\end{tabular}


Appendix A6

Table A6

Compilation of Palaeozoic U-Pb geochronological data from the Alice Springs Orogen (the Arunta Region)

\begin{tabular}{|c|c|c|c|c|}
\hline location & $\begin{array}{l}\text { Age } \\
(\mathrm{Ma})\end{array}$ & $\begin{array}{l}\text { Error } \\
(\mathrm{Ma}) \\
\end{array}$ & Method & Reference \\
\hline \multicolumn{5}{|c|}{ magmatic ages } \\
\hline Brett Creek, N Harts Range & 327 & 3 & SHRIMP U-Pb monazite & 1-Buick et al., 2008 \\
\hline Brett Creek, N Harts Range & 455 & 4 & SHRIMP U-Pb zircon & Buick et al., 2008 \\
\hline Brett Creek, N Harts Range & 454 & 5 & SHRIMP U-Pb zircon & Buick et al., 2008 \\
\hline Brett Creek, N Harts Range & 454 & 9 & SHRIMP U-Pb monazite & Buick et al., 2008 \\
\hline Brett Creek, N Harts Range & 364 & 8 & SHRIMP U-Pb monazite & Buick et al., 2008 \\
\hline Brett Creek, N Harts Range & 392 & 16 & SHRIMP U-Pb monazite & Buick et al., 2008 \\
\hline Brett Creek, N Harts Range & 376 & 16 & SHRIMP U-Pb monazite & Buick et al., 2008 \\
\hline Brett Creek, N Harts Range & 386 & 6 & SHRIMP U-Pb monazite & Buick et al., 2008 \\
\hline Brett Creek, N Harts Range & 408 & 25 & SHRIMP U-Pb monazite & Buick et al., 2008 \\
\hline Brett Creek, N Harts Range & 399 & 18 & SHRIMP U-Pb monazite & Buick et al., 2008 \\
\hline Brett Creek, N Harts Range & 383 & 15 & SHRIMP U-Pb monazite & Buick et al., 2008 \\
\hline Brett Creek, N Harts Range & 380 & 16 & SHRIMP U-Pb monazite & Buick et al., 2008 \\
\hline Brett Creek, N Harts Range & 389 & 14 & SHRIMP U-Pb monazite & Buick et al., 2008 \\
\hline Brett Creek, N Harts Range & 348 & 10 & SHRIMP U-Pb zircon & Buick et al., 2008 \\
\hline Brett Creek, N Harts Range & 341 & 4 & SHRIMP U-Pb monazite & Buick et al., 2008 \\
\hline Brett Creek, N Harts Range & 345 & 23 & SHRIMP U-Pb monazite & Buick et al., 2008 \\
\hline Brett Creek, N Harts Range & 324 & 5 & SHRIMP U-Pb monazite & Buick et al., 2008 \\
\hline Brett Creek, N Harts Range & 320 & 4 & SHRIMP U-Pb monazite & Buick et al., 2008 \\
\hline Brett Creek, N Harts Range & 313 & 5 & SHRIMP U-Pb monazite & Buick et al., 2008 \\
\hline Harts Range & 361 & 2 & SHRIMP U-Pb monazite & Buick et al., 2008 \\
\hline Harts Range & 454 & 8 & SHRIMP U-Pb zircon & Buick et al., 2008 \\
\hline Harts Range & 439 & 14 & SHRIMP U-Pb zircon & Buick et al., 2008 \\
\hline Harts Range & 438 & 6 & SHRIMP U-Pb monazite & Buick et al., 2008 \\
\hline Harts Range & 415 & 6 & SHRIMP U-Pb monazite & Buick et al., 2008 \\
\hline Harts Range & 448 & 7 & SHRIMP U-Pb monazite & Buick et al., 2008 \\
\hline Harts Range & 443 & 23 & SHRIMP U-Pb monazite & Buick et al., 2008 \\
\hline Harts Range & 320 & 6 & SHRIMP U-Pb monazite & Buick et al., 2008 \\
\hline Harts Range & 420 & 8 & SHRIMP U-Pb monazite & Buick et al., 2008 \\
\hline Harts Range & 425 & 11 & SHRIMP U-Pb monazite & Buick et al., 2008 \\
\hline Entia Gneiss Complex & 334 & 15 & SHRIMP U-Pb zircon & Buick et al., 2008 \\
\hline Harts Range & 335 & 9 & SHRIMP U-Pb zircon & Buick et al., 2008 \\
\hline \multicolumn{5}{|c|}{ Metamophic ages } \\
\hline SE Entia Gneiss Complex & 330 & 6 & SHRIMP U-Pb zircon overgrowths & 2-Hand et al., 1999 \\
\hline SE Entia Gneiss Complex & 343 & 8 & SHRIMP U-Pb monazite & Hand et al., 1999 \\
\hline Harts Range & 467 & 8 & SHRIMP U-Pb monazite & Hand et al., 1999 \\
\hline the Entire Point Shear Zone, Huckitta region & 445 & 5 & SHRIMP U-Pb monazite & 3-Scrimgeour and Raith, 2001 \\
\hline Huckitta & 332 & 3 & SHRIMP U-Pb zircon overgrowths & 4-Maidment, 2005 \\
\hline Harts Range & 365 & 10 & SHRIMP U-Pb zircon overgrowths & 5-Maidment et al., 2013 \\
\hline Harts Range & 359 & 6 & SHRIMP U-Pb zircon overgrowths & Maidment et al., 2013 \\
\hline Harts Range & 361 & 5 & SHRIMP U-Pb zircon overgrowths & Maidment et al., 2013 \\
\hline Harts Range & 379 & 5 & SHRIMP U-Pb zircon overgrowths & Maidment et al., 2013 \\
\hline Peaked Hill Shear Zone, Reynolds Range & 354 & 3 & LA-ICP-MS U-Pb monazite & 6-Raimondo et al., 2012 \\
\hline Peaked Hill Shear Zone, Reynolds Range & 360 & 3 & LA-ICP-MS U-Pb monazite & Raimondo et al., 2012 \\
\hline southern Mount Liebig range & 376 & 1 & 40Ar/39Ar age of muscovite & 7-McLaren et al., 2009 \\
\hline northern Mount Liebig range & 401 & 1 & 40Ar/39Ar age of muscovite & McLaren et al., 2009 \\
\hline Southeastern Reynolds Range & 334 & 3 & $40 \mathrm{Ar} / 39 \mathrm{Ar}$ age of muscovite & 8-Cartwright et al., 1999 \\
\hline Southeastern Reynolds Range & 333 & 2 & 40Ar/39Ar age of muscovite & Cartwright et al., 1999 \\
\hline Southeastern Reynolds Range & 334 & 2 & 40Ar/39Ar age of muscovite & Cartwright et al., 1999 \\
\hline Southeastern Reynolds Range & 335 & 4 & 40Ar/39Ar age of muscovite & Cartwright et al., 1999 \\
\hline the Ruby Gap duplex & 311 & 3 & $\mathrm{~K} / \mathrm{Ar}$ of white micas & 9-Dunlap et al., 1991 \\
\hline the Ruby Gap duplex & 312 & 0 & $40 \mathrm{Ar} / 39 \mathrm{Ar}$ age of white micas & Dunlap et al., 1991 \\
\hline the Ruby Gap duplex & 317 & 4 & $\mathrm{~K} / \mathrm{Ar}$ of white micas & Dunlap et al., 1991 \\
\hline the Ruby Gap duplex & 318 & 0 & $40 \mathrm{Ar} / 39 \mathrm{Ar}$ age of white micas & Dunlap et al., 1991 \\
\hline the Ruby Gap duplex & 318 & 5 & $\mathrm{~K} / \mathrm{Ar}$ of white micas & Dunlap et al., 1991 \\
\hline the Ruby Gap duplex & 324 & 4 & $\mathrm{~K} / \mathrm{Ar}$ of white micas & Dunlap et al., 1991 \\
\hline the Ruby Gap duplex & 322 & 1 & $40 \mathrm{Ar} / 39 \mathrm{Ar}$ age of white micas & Dunlap et al., 1991 \\
\hline the Ruby Gap duplex & 377 & 4 & $\mathrm{~K} / \mathrm{Ar}$ of white micas & Dunlap et al., 1991 \\
\hline the Ruby Gap duplex & 375 & 4 & $\mathrm{~K} / \mathrm{Ar}$ of white micas & Dunlap et al., 1991 \\
\hline the Ruby Gap duplex & 339 & 4 & $\mathrm{~K} / \mathrm{Ar}$ of white micas & Dunlap et al., 1991 \\
\hline the Ruby Gap duplex & 328 & 1 & $40 \mathrm{Ar} / 39 \mathrm{Ar}$ age of white micas & Dunlap et al., 1991 \\
\hline the Ruby Gap duplex & 340 & 4 & $\mathrm{~K} / \mathrm{Ar}$ of white micas & Dunlap et al., 1991 \\
\hline the Ruby Gap duplex & 414 & 4 & $\mathrm{~K} / \mathrm{Ar}$ of white micas & Dunlap et al., 1991 \\
\hline Harry Creek Area & 355 & 4 & $\mathrm{~K} / \mathrm{Ar}$ of white micas & 10-Allen and Stubbs, 1982 \\
\hline Harry Creek Area & 352 & 1 & $40 \mathrm{Ar} / 39 \mathrm{Ar}$ age of white micas & Allen and Stubbs, 1982 \\
\hline
\end{tabular}




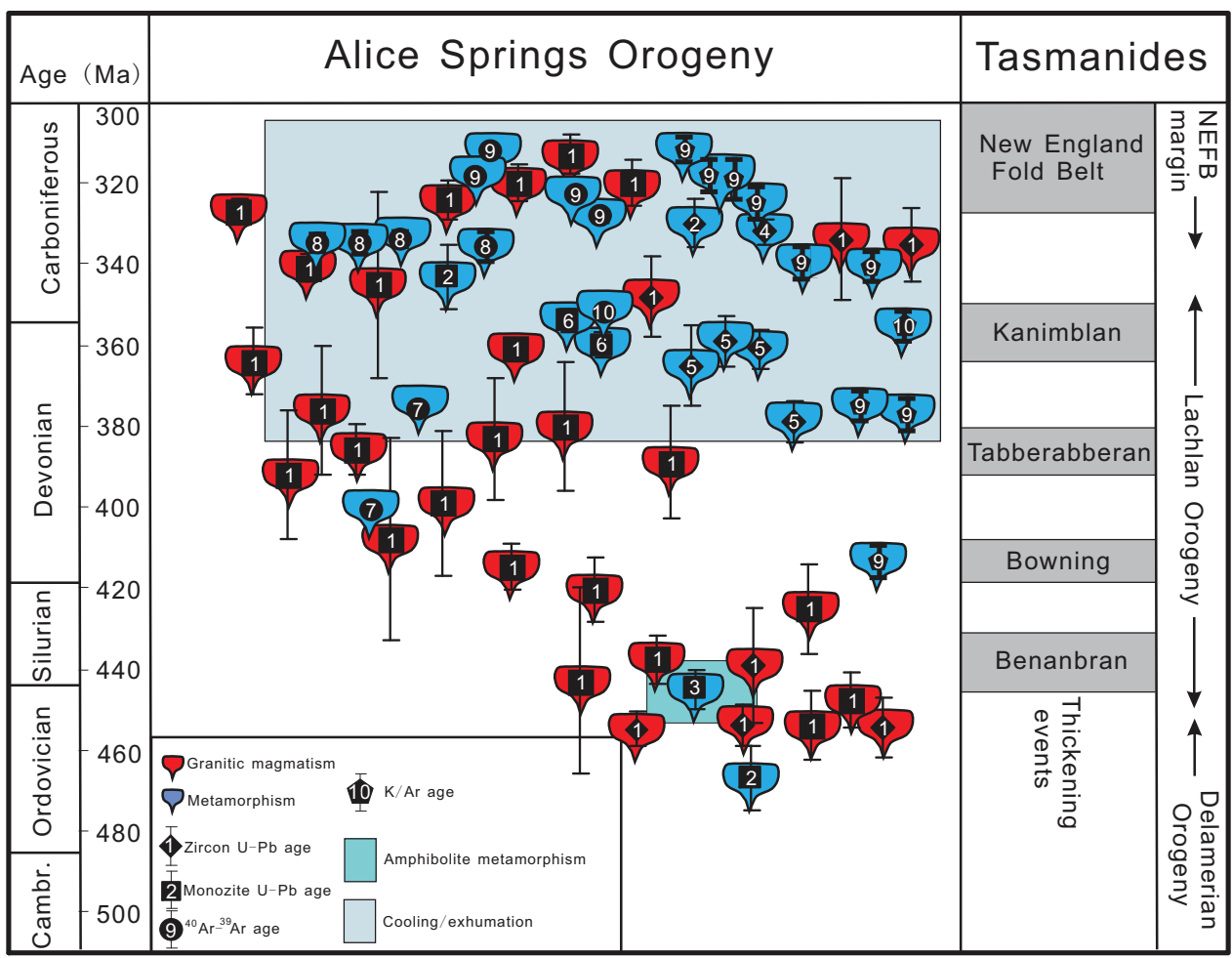

Fig. A6-1. Compilation of tectonothermal events associated with the Alice Springs Orogeny in Central Australia. The data indicate a correlation of the event with subduction along the Proto-Pacific margin of east Australia. Numbers on data points refer to the following sources: 1 (Buick and others, 2008), 2 (Hand and others, 1999), 3 (Scrimgeour and Raith, 2001), 4 (Maidment, 2005), 5 (Maidment and others, 2013), 6 (Raimondo and others, 2012), 7 (McLaren and others, 2009), 8 (Cartwright and others, 1999), 9 (Dunlap and others, 1991), 10 (Allen and Stubbs, 1982). Data details and references are given in table A6. 


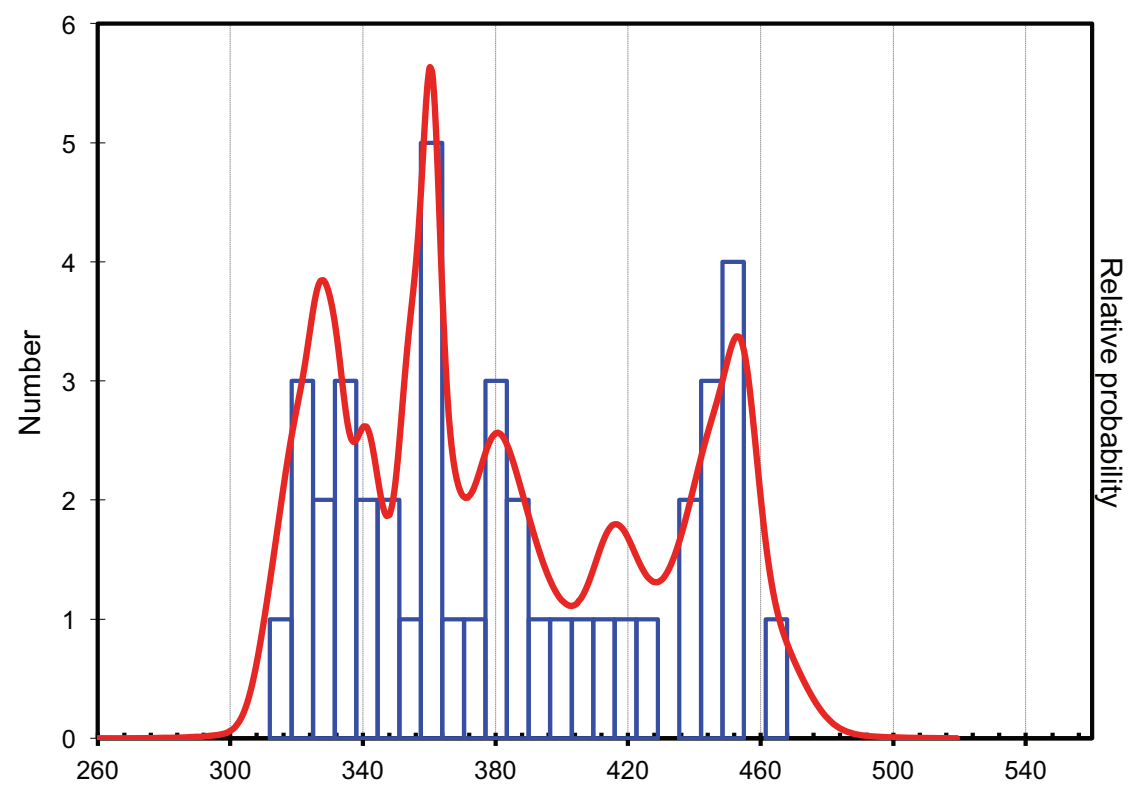

Fig. A6-2. Probability density of ages for the tectonothermal events associated with the Alice Springs Orogeny in Central Australia. The data indicate a correlation of the event with subduction along the Proto-Pacific margin of east Australia. Numbers on data points refer to the following sources: 1 (Buick and others, 2008), 2 (Hand and others, 1999), 3 (Scrimgeour and Raith, 2001), 4 (Maidment, 2005), 5 (Maidment and others, 2013), 6 (Raimondo and others, 2012), 7 (McLaren and others, 2009), 8 (Cartwright and others, 1999), 9 (Dunlap and others, 1991), 10 (Allen and Stubbs, 1982). Data details and references are given in table A6. 


\section{REFERENCES}

Aitken, A. R. A., Betts, P. G., and Ailleres, L., 2009, The architecture, kinematics, and lithospheric processes of a compressional intraplate orogen occurring under Gondwana assembly: The Petermann orogeny, central Australia: Lithosphere, v. 1, n. 6, p. 343-357, http://dx.doi.org/10.1130/L39.1

Aitken, A. R. A., Raimondo, T., and Capitanio, F. A., 2013, The intraplate character of supercontinent tectonics: Gondwana Research, v. 24, n. 3-4, p. 807-814, http://dx.doi.org/10.1016/j.gr.2013.03.005

Allen, A. R., and Stubbs, D., 1982, An ${ }^{40} \mathrm{Ar} /{ }^{39} \mathrm{Ar}$ study of a polymetamorphic complex in the Arunta Block, Central Australia: Contributions to Mineralogy and Petrology, v. 79, n. 3, p. 319-332, http://dx.doi.org/ $10.1007 / \mathrm{BF} 00371524$

Barnes, J. D., Selverstone, J., and Sharp, Z. D., 2004, Interactions between serpentinite devolatilization, metasomatism and strike-slip strain localization during deep crustal shearing in the Eastern Alps: Journal of Metamorphic Geology, v. 22, n. 4, p. 283-300, http://dx.doi.org/10.1111/j.15251314.2004.00514.x

Bea, F., 2012, The sources of energy for crustal melting and the geochemistry of heat-producing elements: Lithos, v. 153, p. 278-291, http://dx.doi.org/10.1016/j.lithos.2012.01.017

Boger, S. D., Wilson, C. J. L., and Fanning, C. M., 2001, Early Paleozoic tectonism within the East Antarctic craton: The final suture between east and west Gondwana?: Geology, v. 29, n. 5, p. 463-466, http:// dx.doi.org/10.1130/0091-7613(2001)029<0463:EPTWTE > 2.0.CO;2

Braun, J., and Shaw, R. D., 1998, Contrasting styles of lithospheric deformation along the northern margin of the Amadeus Basin, Central Australia, in Braun, J., Dooley, J., Goleby, B., van der Hilst, R., and Klootwijk, C., editors, Structure and Evolution of the Australian Continent. Geodynamics: Geodynamics Series, v. 26, p. 139-155, http://dx.doi.org/10.1002/9781118670095.ch10

Braun, J., and Shaw, R., 2001, A thin-plate model of Palaeozoic deformation of the Australian lithosphere: Implications for understanding the dynamics of intracratonic deformation: Geological Society, London, Special Publications, v. 184, p. 165-193, http://dx.doi.org/10.1144/GSL.SP.2001.184.01.09

Brown, M., 2013, Granite: from genesis to emplacement: Geological Society of America Bulletin, v. 125 n.7-8, p. 1079-1113, http:/ /dx.doi.org/10.1130/B30877.1

Buick, I. S., Storkey, A., and Williams, I. S., 2008, Timing relationships between pegmatite emplacement, metamorphism and deformation during the intra-plate Alice Springs Orogeny, central Australia: Journal of Metamorphic Geology, v. 26, n. 9, p. 915-936, http://dx.doi.org/10.1111/j.15251314.2008.00794.x

Burov, E. B., and Watts, A. B., 2006, The long-term strength of the continental lithosphere: "jelly sandwich" or "crème brûlée"?: GSA Today, v. 16, n. 1, p. 4-10, http://dx.doi.org/10.1130/1052-5173(2006)016<4: TLTSOC $>2.0 . \mathrm{CO} ; 2$

Burrett, C., Long, J., and Stait, B., 1990, Early-Middle Palaeozoic biogeography of Asian terranes derived from Gondwana, in McKerrow, W. S., and Scotese, C. R., editors, Palaeozoic Palaeogeography and Biogeography: Geological Society, London, Memoirs, v. 12, p. 163-174, http://dx.doi.org/10.1144/ GSL.MEM.1990.012.01.14

Carter, A., Roques, D., Bristow, C., and Kinny, P., 2001, Understanding Mesozoic accretion in Southeast Asia: Significance of Triassic thermotectonism (Indosinian orogeny) in Vietnam: Geology, v. 29, n. 3, p. 211-214, http://dx.doi.org/10.1130/0091-7613(2001)029<0211:UMAISA > 2.0.CO;2

Cartwright, I., and Barnicoat, A. C., 2003, Geochemical and stable isotope resetting in shear zones from Täschalp: Constraints on fluid flow during exhumation in the Western Alps: Journal of Metamorphic Geology, v. 21, n. 2, p. 143-161, http://dx.doi.org/10.1046/j.1525-1314.2003.00423.x

Cartwright, I., Buick, I. S., Foster, D. A., and Lambert, D. D., 1999, Alice Springs age shear zones from the southeastern Reynolds Range, central Australia: Australian Journal of Earth Sciences, v. 46, n. 3, p. 355-363, http://dx.doi.org/10.1046/j.1440-0952.1999.00710.x

Catlos, E. J., Harrison, T. M., Manning, C. E., Grove, M., Rai, S. M., Hubbard, M. S., and Upreti, B. N., 2002, Record of the evolution of the Himalaya orogen from in situ Th-Pb ion microprobe dating of monazite: Eastern Nepal and western Garhwal: Journal of Asian Earth Sciences, v. 20, n. 5, p. 459-479, http:// dx.doi.org/10.1016/S1367-9120(01)00039-6

Cawood, P. A., 2005, Terra Australis Orogen: Rodinia breakup and development of the Pacific and Iapetus margins of Gondwana during the Neoproterozoic and Paleozoic: Earth-Science Reviews, v. 69, n. 3-4, p. 249-279, http://dx.doi.org/10.1016/j.earscirev.2004.09.001

Cawood, P. A., and Buchan C., 2007, Linking accretionary orogenesis with supercontinent assembly: Earth-Science Reviews, v. 82, n. 3-4, p. 217-256, http://dx.doi.org/10.1016/j.earscirev.2007.03.003

Cawood, P. A., Johnson, M. R. W., and Nemchin, A. A., 2007, Early Palaeozoic orogenesis along the Indian margin of Gondwana: Tectonic response to Gondwana assembly: Earth and Planetary Science Letters, v. 255, n. 1-2, p. 70-84, http://dx.doi.org/10.1016/j.epsl.2006.12.006

Cawood, P. A., Kröner, A., Collins, W. J., Kusky, T. M., Mooney, W. D., and Windley, B. F., 2009, Accretionary orogens through Earth history, in Cawood, P. A., and Kröner, A., editors, Earth Accretionary Systems in Space and Time: Geological Society, London, Special Publications, v. 318, p. 1-36, http://dx.doi.org/ $10.1144 / \mathrm{sp} 318.1$

Cawood, P. A., Leitch, E. C., Merle, R. E., and Nemchin, A. A., 2011, Orogenesis without collision: Stabilizing the Terra Australis accretionary orogen, eastern Australia: Geological Society of America Bulletin, v. 123, n. 11-12, p. 2240-2255, http://dx.doi.org/10.1130/B30415.1

Cawood, P. A., Wang, Y. J., Xu, Y. J., and Zhao, G. C., 2013, Locating South China in Rodinia and Gondwana: A fragment of Greater India Lithosphere?: Geology, v. 41, n. 8, p. 903-906, http://dx.doi.org/10.1130/ G34395.1

Charvet, J., 2013, The Neoproterozoic-Early Paleozoic tectonic evolution of the South China Block: An 
overview: Journal of Asian Earth Sciences, v. 74, p. 198-209, http://dx.doi.org/10.1016/j.jseaes. 2013.02.015

Charvet, J., Shu, L. S., Shi, Y. S., Guo, L. Z., and Faure, M., 1996, The building of South China: collision of Yangzi and Cathaysia blocks, problems and tentative answers: Journal of Southeast Asian Earth Sciences, v. 13, n. 3-5, p. 223-235, http://dx.doi.org/10.1016/0743-9547(96)00029-3

Charvet, J., Cluzel, D., Faure, M., Caridroit, M., Shu, L. S., and Lu, H. F., 1999, Some tectonic aspects of the pre-Jurassic accretionary evolution of east Asia, in Metcalfe, I., Ren, J. S., Charvet, J., and Hada, S., editors, Gondwana Dispersion and Asian Accretion: IGCP 321 Final Results Volume, Rotterdam, Balkema, p. 37-65.

Charvet, J., Shu, L. S., Faure, M., Choulet, F., Wang, B., Lu, H. F., and Le Breton, N., 2010, Structural development of the Lower Paleozoic belt of South China: Genesis of an intracontinental orogen: Journal of Asian Earth Sciences, v. 39, n. 4, p. 309-330, http://dx.doi.org/10.1016/j.jseaes.2010.03.006

Chen, B., and Zhuang, Y. X., 1994, The petrology and petrogenesis of Yunlu charnockite and its granulite inclusion, west Guangdong, South China: Acta Petrologica Sinica, v. 10, n. 2, p. 139-149.

Chen, C. H., Lee, C. Y., Hsieh, P. S., Zeng, W., and Zhou, H. W., 2008, Approaching the age problem for some metamorphosed Precambrian basement rocks and Phanerozoic granitic bodies in the Wuyishan area: The application of EMP monazite age dating: Geological Journal of China Universities, v. 14, n. 1, p. $1-15$.

Chen, C. H., Liu, Y. H., Lee, C. Y., Xiang, H., and Zhou, H. W., 2012a, Geochronology of granulite, charnockite and gneiss in the poly-metamorphosed Gaozhou Complex (Yunkai massif), South China: Emphasis on the in-situ EMP monazite dating: Lithos, v. 144-145, p. 109-129, http://dx.doi.org/ 10.1016/j.lithos.2012.04.009

Chen, L., Berntsson, F., Zhang, Z. J., Wang, P., Wu, J., and Xu, T., 2014, Seismically constrained thermo-rheological structure of the eastern Tibetan margin: Implication for lithospheric delamination: Tectonophysics, v. 627, p. 122-134, http://dx.doi.org/10.1016/j.tecto.2013.11.005

Chen, W. P., and Molnar, P., 1983, Focal depths of intracontinental and intraplate earthquakes and their implications for the thermal and mechanical properties of the lithosphere: Journal of Geophysical Research-Solid Earth, v. 88, n. B5, p. 4183-4214, http://dx.doi.org/10.1029/JB088iB05p04183

Chen, X., Zhang, Y. D., Fan, J. X., Cheng, J. F., and Li, Q. J., 2010, Ordovician graptolite-bearing strata in southern Jiangxi with a special reference to the Kwangsian Orogeny: Science China: Earth Sciences, v. 53 n. 11, p. 1602-1610, http://dx.doi.org/10.1007/s11430-010-4117-6

Chen, X., Zhang, Y. D., Fan, J. X., Tang, L., and Sun, H. Q., 2012b, Onset of the Kwangsian Orogeny as evidenced by biofacies and lithofacies: Science China: Earth Sciences, v. 55, n. 10, p. 1592-1600, http://dx.doi.org/10.1007/s11430-012-4490-4

Chen X., Fan, J. X., Chen, Q., Tang, L., and Hou, X. D., 2014, Toward a stepwise Kwangsian Orogeny: Science China: Earth Sciences, v. 57, n. 3, p. 379-387, http://dx.doi.org/10.1007/s11430-013-4815-y

Cloetingh, S., Burov, E., and Francois, T., 2013, Thermo-mechanical controls on intra-plate deformation and the role of plume-folding interactions in continental topography: Gondwana Research, v. 24, n. 3-4, p. 815-837, http://dx.doi.org/10.1016/j.gr.2012.11.012

Collins, W. J., 2002, Hot orogens, tectonic switching, and creation of continental crust: Geology, v. 30, n. 6 , p. 535-538, http://dx.doi.org/10.1130/0091-7613(2002) 030<0535:HOTSAC $>2.0$.CO;2

Cunningham, D., 2013, Mountain building processes in intracontinental oblique deformation belts: Lessons from the Gobi Corridor, Central Asia: Journal of Structural Geology, v. 46, p. 255-282, http://dx.doi.org/ 10.1016/j.jsg.2012.08.010

DeCelles, P. G., Gehrels, G. E., Quade, J., LaReau, B., and Spurlin, M., 2000, Tectonic implications of U-Pb zircon ages of the Himalayan orogenic belt in Nepal: Science, v. 288, n. 5465, p. 497-499, http:// dx.doi.org/10.1126/science.288.5465.497

Deng, Y., Zhang, Z., Badal, J., and Fan, W., 2014, 3-D density structure under South China constrained by seismic velocity and gravity data: Tectonophysics, v. 627, p. 159-170, http://dx.doi.org/10.1016/ j.tecto.2013.07.032

Ding, S. J., Xu, C. H., Long, W. G., Zhou, Z. Y., and Liao, Z. T., 2002, Tectonic attribute and geochronology of metavolcanic rocks, Tunchang, Hainan Island: Acta Petrologica Sinica, v. 18, p. 83-90.

Dong, Y. P., Liu, X. M., Neubauer, F., Zhang, G. W., Tao, N., Zhang, Y. G., Zhang, X. N., and Li, W., 2013, Timing of Paleozoic amalgamation between the North China and South China Blocks: Evidence from detrital zircon U-Pb ages: Tectonophysics, v. 586, p. 173-191, http://dx.doi.org/10.1016/ j.tecto.2012.11.018

Dunlap, W. J., Teyssier, C., McDougall, I., and Baldwin, S., 1991, Ages of deformation from K/Ar and ${ }_{40} \mathrm{Ar} /{ }^{39} \mathrm{Ar}$ dating of white micas: Geology, v. 19, n. 2, p. 1213-1216, http://dx.doi.org/10.1130/00917613(1991) $019<1213:$ AODFKA $>2.3$. CO;2

Faure, M., Shu, L. S., Wang, B., Charvet, J., Choulet, F., and Monié, P., 2009, Intracontinental subduction: A possible mechanism for the Early Paleozoic Orogen of SE China: Terra Nova, v. 21, n. 5, p. 360-368, http://dx.doi.org/10.1111/j.1365-3121.2009.00888.x

Feng, S. J., Zhao, K. D., Ling, H. F., Chen, P. R., Chen, W. F., Sun, T., Jiang, S. Y., and Pu, W., 2014, Geochronology, elemental and Nd-Hf isotopic geochemistry of Devonian A-type granites in central Jiangxi, South China: Constraints on petrogenesis and post-collisional extension of the Wuyi-Yunkai orogeny: Lithos, v. 206-207, p. 1-18, http:/ /dx.doi.org/10.1016/j.lithos.2014.07.007

Findlay, R. H., 1997, The Song Ma Anticinorium, northern Vietnam: The structure of an allochthonous terrane containing an early Palaeozoic island arc sequence: Journal of Asian Earth Sciences, v. 15, n. 6, p. 453-464, http://dx.doi.org/10.1016/S0743-9547(97)00031-7

Gardner, R. L. Daczko, N. R., Halpin, J. A., and Whittaker, J. M., 2014, Discovery of a microcontinent (Gulden Draak Knoll) offshore Western Australia: Implications for East Gondwana reconstructions: Gondwana Research, v. 28, n. 3, p. 1019-1031, http://dx.doi.org/10.1016/j.gr.2014.08.013. 
Gehrels, G. E., DeCelles, P. G., Ojha, T. P., and Upreti, B. N., 2006a, Geologic and U-Th-Pb geochronologic evidence for early Paleozoic tectonism in the Kathmandu thrust sheet, central Nepal Himalaya: Geological Society of America Bulletin, v. 118, n. 1-2, p. 185-198, http://dx.doi.org/10.1130/ B25753.1

2006b, Geologic and U-Pb geochronologic evidence for early Paleozoic tectonism in the Dadeldhura thrust sheet, far-west Nepal Himalaya: Journal of Asian Earth Sciences, v. 28, n. 4-6, p. 385-408, http://dx.doi.org/10.1016/j.jseaes.2005.09.012

Gorczyk, W., Hobbs, B., Gessner, K., and Gerya, T., 2013, Intracratonic geodynamics: Gondwana Research, v. 24 n. 3-4, p. 838-848, http://dx.doi.org/10.1016/j.gr.2013.01.006

Guan, Y., Yuan, C., Sun, M., Wilde, S., Long, X., Huang, X., and Wang, Q., 2014, I-type granitoids in the eastern Yangtze Block: Implications for the Early Paleozoic intracontinental orogeny in South China: Lithos, v. 206-207, p. 34-51, http://dx.doi.org/10.1016/j.lithos.2014.07.016

Gueydan, F., Leroy, Y. M., Jolivet, L., and Agard, P., 2003, Analysis of continental midcrustal strain localization induced by microfracturing and reaction-softening: Journal of Geophysical Research-Solid Earth, v. 108, n. B2, p. 2064, http://dx.doi.org/10.1029/2001JB000611

Guynn, J., Kapp, P., Gehrels, G. E., and Ding, L., 2012, U-Pb geochronology of basement rocks in central Tibet and paleogeographic implications: Journal of Asian Earth Sciences, v. 43, n. 1, p. 23-50, http:// dx.doi.org/10.1016/j.jseaes.2011.09.003

Hand, M., and Sandiford, M., 1999, Intraplate deformation in central Australia, the link between subsidence and fault reactivation: Tectonophysics, v. 305, n. 1-3, p. 121-140, http://dx.doi.org/10.1016/S00401951(99) 00009-8

Hand, M., Mawby, J., Kinny, P., and Foden, J., 1999, U-Pb ages from the Harts Range, central Australia: Evidence for early Ordovician extension and constraints on Carboniferous metamorphism: Journal of the Geological Society, v. 156, n. 4, p. 715-730, http://dx.doi.org/10.1144/gsjgs.156.4.0715

Heidbach, O., Tingay, M., Barth, A., Reinecker, J., Kurfe $\beta$, D., and Müller, B., 2010, Global crustal stress pattern based on the World Stress Map database release 2008: Tectonophysics, v. 482 n. 1-4, p. 3-15, http:/ /dx.doi.org/10.1016/j.tecto.2009.07.023

Holdsworth, R. E., Stewart, M., Imber, J., and Strachan, R. A., 2001, The structure and rheological evolution of reactivated continental fault zones: A review and case study, in Miller, J. A., Holdsworth, R. E., Buick, I. S., and Hand, M., editors, Continental Reactivation and Reworking: Geological Society, London, Special Publications, v. 184, p. 115-137, http://dx.doi.org/10.1144/GSL.SP.2001.184.01.07

Huang, X.-L., Yu, Y., Li, J., Tong, L.-X., and Chen, L.-L., 2013, Geochronology and petrogenesis of the early Paleozoic I-type granite in the Taishan area, South China: Middle-lower crustal melting during orogenic collapse: Lithos, v. 177, p. 268-284, http://dx.doi.org/10.1016/j.lithos.2013.07.002

Hughes, N. C., Myrow, P. M., Mckenzie, R. N., Harper, D. A. T., Nhargava, O. N., Tangri, S. K., Ghalley, K. S., and Fanning, C. M., 2011, Cambrian rocks and faunas of the Wachi La, Black Mountains, Bhutan: Geological Magazine, v. 148, n. 3, p. 351-379, http://dx.doi.org/10.1017/S0016756810000750

Isozaki, Y., 2011, Ordovician rocks in Japan, in Gutierrez-Marco, J. C., Rabano, I., and Garcia-Bollido, D., editors, Ordovician of the World: Madrid, Instituto Geologico y Minero de Espana, Cuadernos Museo Geominero, v. 14, p. 251-252.

Isozaki, Y., Aoki, K., Nakama, T., and Yanai, S., 2010, New insight into a subduction-related orogen: A reappraisal of the geotectonic framework and evolution of the Japanese Islands: Gondwana Research, v. 18, n. 1, p. 82-105, http://dx.doi.org/10.1016/j.gr.2010.02.015

Isozaki, Y., Ehiro, M., Nakahata, H., Aoki, K., Sakata, S., and Hirata, T., 2015, Cambrian plutonism in Northeast Japan and its significance for the earliest arc-trench system of proto-Japan: New U-Pb zircon ages of the oldest granitoids in the Kitakami and Ou Mountains: Journal of Asian Earth Sciences, v. 108, p. 136-149, http://dx.doi.org/10.1016/j.jseaes.2015.04.024

Jackson, J., 2002, Strength of the continental lithosphere: Time to abandon the jelly sandwich?: GSA Today, v. 12, n. 9, p. 4-9, http://dx.doi.org/10.1130/1052-5173(2002)012<0004:SOTCLT>2.0.CO;2

Jackson, J. A., Austrheim, H., McKenzie, D., and Priestley, K., 2004, Metastability, mechanical strength, and the support of mountain belts: Geology, v. 32 n. 7, p. 625-628, http://dx.doi.org/10.1130/G20397.1

Jackson, J., McKenzie, D. A. N., Priestley, K., and Emmerson, B., 2008, New views on the structure and rheology of the lithosphere:Journal of the Geological Society, v. 165 n. 2, p. 453-465, http://dx.doi.org/ 10.1144/0016-76492007-109

Jamtveit, B., Malthe-Sørenssen, A., and Kostenko, O., 2008, Reaction enhanced permeability during retrogressive metamorphism: Earth and Planetary Science Letters, v. 267, n. 3-4, p. 620-627, http:/9 dx.doi.org/10.1016/j.epsl.2007.12.016

Jamtveit, B., Putnis, C. V., and Malthe-Sørenssen, A., 2009, Reaction induced fracturing during replacement processes: Contributions to Mineralogy and Petrology, v. 157 n. 1, p. 127-133, http://dx.doi.org/ $10.1007 / \mathrm{s} 00410-008-0324-y$

Jiang, G., Sohl, L. E., and Christie-Blick, N., 2003, Neoproterozoic stratigraphic comparison of the Lesser Himalaya (India) and Yangtze block (South China): Paleogeographic implications: Geology, v. 31, n. 10, p. 917-920, http://dx.doi.org/10.1130/G19790.1

Johnson, M. R. W., Oliver, G. J. H., Parrish, R. R., and Johnson, S. P., 2001, Synthrusting metamorphism, cooling and erosion of the Himalayan Kathmandu complex, Nepal: Tectonics, v. 20, n. 3, p. 394-415, http://dx.doi.org/10.1029/2001TC900005

Kim, S. W., Oh, C. W., Williams, I. S., Rubatto, D., Ryu, In-C., Rajesh, V. J., Kim, C. B., Guo, J., and Zhai, M., 2006, Phanerozoic high-pressure eclogite and intermediate-pressure granulite facies metamorphism in the Gyeonggi Massif, South Korea: Implications for the eastward extension of the Dabie-Sulu continental collision zone: Lithos, v. 92, n. 3-4, p. 357-377, http://dx.doi.org/10.1016/j.lithos.2006.03.050

Kim, S. W., Kwon, S., Santosh, M., Cho, D. L., and Ryu, In-C., 2014, Detrital zircon U-Pb geochronology and 
tectonic implications of the Paleozoic sequences in western South Korea: Journal of Asian Earth Sciences, v. 95, p. 217-227, http://dx.doi.org/10.1016/j.jseaes.2014.05.022

Korhonen, F. J., and Johnson, S. P., 2015, The role of radiogenic heat in prolonged intraplate reworking: The Capricorn Orogen explained?: Earth and Planetary Science Letters, v. 428, p. 22-32, http:// dx.doi.org/10.1016/j.epsl.2015.06.039

Kruse, P. D., 1990, Cambrian palaeontology of the Daly Basin: Northern Territory Geological Survey Report, v. 7, p. 1-58.

Ksienzyk, A. K., Jacobs, J., Boger, S. D., Kosler, J., Sircombe, K. N., and Whitehouse, M. J., 2012, U-Pb ages of metamorphic monazite and detrital zircon from the Northampton complex: evidence of two orogenic cycles in Western Australia: Precambrian Research, v. 198-199, p. 37-50, http://dx.doi.org/10.1016/ j.precamres.2011.12.011

Lee, J., and Whitehouse, M. J., 2007, Onset of mid-crustal extensional flow in southern Tibet: Evidence from $\mathrm{U} / \mathrm{Pb}$ zircon ages: Geology, v. 35, n. 1, p. 45-48, http://dx.doi.org/10.1130/G22842A.1

Lee, J., Hacker, B. R., Dinklage, W. S., Wang, Y., Gans, P., Calvert, A., Wan, J. L., Chen, W. J., Blythe, A. E., and McClelland, W., 2000, Evolution of Kangmar dome, southern Tibet: Structural, petrologic, and thermochronologic constraints: Tectonics, v. 19, n. 5, p. 872-895, http://dx.doi.org/10.1029/ 1999TC001147

Lepvrier, C., van Vuong, N., Maluski, H., Troung Thi, P., and Van Vu, T., 2008, Indosinian tectonics in Vietnam: Comptes Rendus Geoscience, v. 340, n. 2-3, p. 94-111, http://dx.doi.org/10.1016/ j.crte.2007.10.005

Li, X. H., Li, Z. X., Ge, W. C., Zhou, H. W., Li, W. X., Liu, Y., and Wingate, M. T. D., 2003, Neoproterozoic granitoids in South China: Crustal melting above a mantle plume at ca. 825 Ma?: Precambrian Research, v. 122, n. 1-4, p. 45-83, http://dx.doi.org/10.1016/S0301-9268(02)00207-3

Li, X. H., Li, W. X., Li, Z. X., and Liu, Y., 2008a, 850-790 Ma bimodal volcanic and intrusive rocks in northern Zhejiang, South China: A major episode of continental rift magmatism during the breakup of Rodinia: Lithos, v. 102, n. 1-2, p. 341-357, http://dx.doi.org/10.1016/j.lithos.2007.04.007

Li, Z. X., 1998, Tectonic history of the major East Asian lithospheric blocks since the mid-Proterozoic - a synthesis, in Flower, M. F. J., Chung, S. L., Lo, C. H., and Lee, T. Y., editors, Mantle Dynamics and Plate Interactions in East Asia: Washington D.C., American Geophysical Union, Geodynamic Series, v. 27, p. 221-243, http://dx.doi.org/10.1029/GD027p0221

Li, Z. X., Bogdanova, S. V., Collins, A. S., Davidson, A., De Waele, B., Ernst, R. E., Fitzsimons, I. C. W., Fuck, R. A., Gladkochub, D. P., Jacobs, J., Karlstrom, K. E., Lu, S., Natapov, L. M., Pease, V., Pisarevsky, S. A., Thrane, K., and Vernikovsky, V., 2008b, Assembly, configuration, and break-up history of Rodinia: A synthesis: Precambrian Research, v. 160, n. 1-2, p. 179-210, http://dx.doi.org/10.1016/j. precamres.2007.04.021

Li, Z. X., Li, X. H., Wartho, J. A., Clark, C., Li, W. X., Zhang, C. L., and Bao, C. M., 2010, Magmatic and metamorphic events during the Early Paleozoic Wuyi-Yunkai Orogeny, southeastern South China: New age constraints and pressure-temperature conditions: Geological Society of America Bulletin, v. 122, n. 5-6, p. 772-793, http://dx.doi.org/10.1130/B30021.1

Lin, Y. L., Yeh, M. W., Lee, T. Y., Chung, S. L., Iizuka, Y., and Charusiri, P., 2013, First evidence of the Cambrian basement in Upper Peninsula of Thailand and its implication for crustal and tectonic evolution of the Sibumasu terrane: Gondwana Research, v. 24, n. 3-4, p. 1031-1037, http://dx.doi.org/ 10.1016/j.gr.2013.05.014

Liu, R., Zhou, H., Zhang, L., Zhong, Z., Zeng, W., Xiang, H., Jin, S., Lu, X., and Li, C., 2010, Zircon U-Pb ages and Hf isotope compositions of the Mayuan migmatite complex, NW Fujian Province, Southeast China: Constraints on the timing and nature of a regional tectonothermal event associated with the Caledonian orogeny: Lithos, v. 119, n. 3-4, p. 163-180, http://dx.doi.org/10.1016/j.lithos.2010.06.004

Liu, S., Hu, R. Z., Gao, S., Feng, C. X., Huang, Z., Lai, S., Yuan, H., Liu, X., Coulson, I. M., Feng, G., Wang, T., and $\mathrm{Qi}, \mathrm{Y}-\mathrm{Q} ., 2009, \mathrm{U}-\mathrm{Pb}$ zircon, geochemical and $\mathrm{Sr}-\mathrm{Nd}-\mathrm{Hf}$ isotopic constraints on the age and origin of Early Palaeozoic I-type granite from the Tengchong-Baoshan Block, Western Yunnan Province, SW China: Journal of Asian Earth Sciences, v. 36, n. 2-3, p. 168-182, http://dx.doi.org/10.1016/ j.jseaes.2009.05.004

Liu, Y., Siebel, W., Massonne, H. J., and Xiao, X. C., 2007, Geochronological and petrological constraints for tectonic evolution of the Central Greater Himalayan sequence in the Kharta Area, Southern Tibet: The Journal of Geology, v. 115, n. 2, p. 215-230, http://dx.doi.org/10.1086/510806

Long, S., McQuarrie, N., Tobgay, T., Rose, C., Gehrels, G., and Grujic, D., 2011, Tectonostratigraphy of the Lesser Himalaya of Bhutan: Implications for the along-strike stratigraphic continuity of the northern Indian margin: Geological Society of America Bulletin, v. 123, n. 7-8, p. 1406-1426, http://dx.doi.org/ 10.1130/B30202.1

Lu, G., Zhao, L., Zheng, T., and Kaus, B. J. P., 2014, Strong intracontinental lithospheric deformation in South China: Implications from seismic observations and geodynamic modeling: Journal of Asian Earth Sciences, v. 86, p. 106-116, http://dx.doi.org/10.1016/j.jseaes.2013.08.020

Maggi, A., Jackson, J. A., McKenzie, D., and Priestley, K., 2000, Earthquake focal depths, effective elastic thickness, and the strength of the continental lithosphere: Geology, v. 28, n. 6, p. 495-498, http:// dx.doi.org/10.1130/0091-7613(2000) 28<495:EFDEET>2.0.CO;2

Maidment, D. W., ms, 2005, Paleozoic high-grade metamorphism within the Centralian Superbasin, Harts Range region, central Australia: Canberra, Australia, Australian National University, Ph. D. thesis, 433 p., http:/ / hdl.handle.net/1885/11033

Maidment, D. W., Hand, M., and Williams, I. S., 2013, High grade metamorphism of sedimentary rocks during Palaeozoic rift basin formation in central Australia: Gondwana Research, v. 24, n. 3-4, p. 865885, http://dx.doi.org/10.1016/j.gr.2012.12.020

Marsh, J. H., Johnson, S. E., Yates, M. G., and West, D. P., Jr., 2009, Coupling of deformation and reactions 
during mid-crustal shear zone development: An in situ frictional-viscous transition: Journal of Metamorphic Geology, v. 27, n. 8, p. 531-553, http://dx.doi.org/10.1111/j.1525-1314.2009.00841.x

McLaren, S., and Sandiford, M., 2001, Long-term thermal consequences of tectonic activity at Mount Isa, Australia: Implications for polyphase tectonism in the Proterozoic, in Miller, J. A., Holdsworth, R. E., Buick, I. S., and Hand, M., editors, Continental Reactivation and Reworking: Geological Society, London, Special Publications, v. 184, p. 219-236, http://dx.doi.org/10.1144/GSL.SP.2001.184.01.11

McLaren, S., Sandiford, M., Dunlap, W. J., Scrimgeour, I., Close, D., and Edgoose, C., 2009, Distribution of Paleozoic reworking in the Western Arunta Region and northwestern Amadeus Basin from ${ }^{40} \mathrm{Ar} /{ }^{39} \mathrm{Ar}$ thermochronology: Implications for the evolution of intracratonic basins: Basin Research, v. 21, n. 3, p. 315-334, http://dx.doi.org/10.1111/j.1365-2117.2008.00385.x

McQuarrie, N., Robinson, D., Long, S., Tobgay, T., Grujic, D., Gehrels, G., and Ducea, M., 2008, Preliminary stratigraphic and structural architecture of Bhutan: Implications for the along-strike architecture of the Himalayan System: Earth and Planetary Science Letters, v. 272, n. 1-2, p. 105-117, http://dx.doi.org/ 10.1016/j.epsl.2008.04.030

McQuarrie, N., Long, S. P., Tobgay, T., Nesbit, J. N., Gehrels, G., and Ducea, M. N., 2013, Documenting basin scale, geometry and provenance through detrital geochemical data: Lessons from the Neoproterozoic to Ordovician Lesser, Greater, and Tethyan Himalayan strata of Bhutan: Gondwana Research, v. 23, n. 4, p. 1491-1510, http://dx.doi.org/10.1016/j.gr.2012.09.002

Meert, J. G., Van der Voo, R., and Ayub, S., 1995, Paleomagnetic investigation of the Neoproterozoic Gagwe lavas and Mbozi Complex, Tanzania and the assembly of Gondwana: Precambrian Research, v. 74, n. 4, p. 225-244, http://dx.doi.org/10.1016/0301-9268(95)00012-T

Miller, J. A., Buick, I. S., Cartwright, I., and Barnicoat, A., 2002, Fluid processes during the exhumation of high- $P$ metamorphic belts: Mineralogical Magazine, v. 66, N. 1, p. 93-119, http://dx.doi.org/10.1180/ 0026461026610016

Myrow, P. M., Hughes, N. C., Searle, M. P., Fanning, C. M., Peng, S. C., and Parcha, S. K., 2009, Stratigraphic correlation of Cambrian-Ordovician deposits along the Himalaya: Implications for the age and nature of rocks in the Mt. Everest region: Geological Society of America Bulletin, v. 121, n. 3-4, p. 323-332, http://dx.doi.org/10.1130/B26384.1

Myrow, P. M., Hughes, N. C., Goodge, J. W., Fanning, C. M., Williams, I. S., Peng, S. C., Bhargava, O. N., Parcha, S. K., and Pogue, K. R., 2010, Extraordinary transport and mixing of sediment across Himalayan central Gondwana during the Cambrian-Ordovician: Geological Society of America Bulletin, v. 122, n. 9-10, p. 1660-1670, http://dx.doi.org/10.1130/B30123.1

Nagy, E. A., Maluski, H., Lepvrier, C., Schärer, U., Thi, P. T., Leyreloup, A., and Thich, V. V., 2001, Geodynamic Significance of the Kontum Massif in Central Vietnam: Composite ${ }^{40} \mathrm{Ar} /{ }^{39} \mathrm{Ar}$ and U-Pb Ages from Paleozoic to Triassic: The Journal of Geology, v. 109, n. 6, p. 755-770, http://dx.doi.org/ $10.1086 / 323193$

Neves, S. P., 2003, Proterozoic history of the Borborema province (NE Brazil): correlations with neighboring cratons and Pan-African belts and implications for the evolution of western Gondwana: Tectonics, v. 22, n. 4, p. 1031, http://dx.doi.org/10.1029/2001TC001352

Neves, S. P., Tommasi, A., Vauchez, A., and Hassani, R., 2008, Intraplate continental deformation: Influence of a heat-producing layer in the lithospheric mantle: Earth and Planetary Science Letters, v. 274, n. 3-4, p. 392-400, http://dx.doi.org/10.1016/j.epsl.2008.07.040

Niemeijer, A. R., and Spiers, C. J., 2005, Influence of phyllosilicates on fault strength in the brittle-ductile transition: Insights from rock analogue experiments: Geological Society, London, Special Publications, v. 245, p. 303-327, http://dx.doi.org/10.1144/GSL.SP.2005.245.01.15

Öpik, A. A., 1975, Templetonian and Ordian xystridurid trilobites of Australia: Bureau of Mineral Resources, Geology and Geophysics Bulletin, v. 121, p. 1-84.

Pisarevsky, S. A., Wingate, M. T. D., Powell, C. M., Johnson, S., and Evans, D. A. D., 2003, Models of Rodina assembly and fragmentation, in Yoshida, M., Windley, B. F., and Dasgupta, S., editors, Proterozoic East Gondwana: Supercontinent Assembly and Break-up: Geological Society, London, Special Publications, v. 206, p. 35-55, http://dx.doi.org/10.1144/GSL.SP.2003.206.01.04

Powell, C. McA., and Pisarevsky, S. A., 2002, Late Neoproterozoic assembly of East Gondwana: Geology, v. 30, n. 1, p. 3-6, http://dx.doi.org/10.1130/0091-7613(2002)030<0003:LNAOEG >2.0.CO;2

Powell, C. McA., Li, Z. X., McElhinny, M. W., Meert, J. G., and Park, J. K., 1993, Palaeomagnetic constraints on timing of the Neoproterozoic breakup of Rodinia and the Cambrian formation of Gondwana: Geology, v. 21, n. 10, p. 889-892, http://dx.doi.org/10.1130/0091-7613(1993)021<0889: PCOTOT $>2.3 . \mathrm{CO} ; 2$

Pullen, A., Kapp, P., Gehrels, G. E., Ding, L., and Zhang, Q. H., 2011, Metamorphic rocks in central Tibet: lateral variations and implications for crustal structure: Geological Society of America Bulletin, v. 123, n. 3-4, p. 585-600, http://dx.doi.org/10.1130/B30154.1

Putnis, A., and Austrheim, H., 2010, Fluid-induced processes: Metasomatism and metamorphism: Geofluids, v. 10, n. 1-2, p. 254-269, http://dx.doi.org/10.1111/j.1468-8123.2010.00285.x

Raimondo, T., Collins, A. S., Hand, M., Walker-Hallam, A., Smithies, R. H., Evins, P. M., and Howard, H. M., 2010, The anatomy of a deep intracontinental orogen: Tectonics, v. 29, n. 4, p. TC4024. http:// dx.doi.org/10.1029/2009TC002504

Raimondo, T., Clark, C., Hand, M., Cliff, J., and Harris, C., 2012, High-resolution geochemical record of fluid-rock interaction in a mid-crustal shear zone: A comparative study of major element and oxygen isotope transport in garnet: Journal of Metamorphic Geology, v. 30, n. 3, p. 255-280, http:/ / dx.doi.org/ $10.1111 /$ j.1525-1314.2011.00966.x

Raimondo, T., Hand, M., and Collins, W. J., 2014, Compressional intracontinental orogens: Ancient and modern perspectives: Earth-Science Reviews, v. 130, p. 128-153, http://dx.doi.org/10.1016/j.earscirev. 2013.11.009 
Ramos, V. A., and Folguera, A., 2009, Andean flat-slab subduction through time, in Murphy, J. B., Keppie, J. D., and Hynes, A. J. editors, Ancient Orogens and Modern Analogues: Geological Society, London, Special Publications, v. 327, p. 31-54, http://dx.doi.org/10.1144/SP327.3

Ramos, V. A., Cristallini, E. O., and Pérez, D. J., 2002, The Pampean flat-slab of the Central Andes: Journal of South American Earth Sciences, v. 15, n. 1, p. 59-78, http://dx.doi.org/10.1016/S0895-9811(02)00006-8

Ren, J. S., 1991, On the geotectonics of southern China: Acta Geologica Sinica (Dizhi Xuebao), v. 4, n. 2 , p. 111-130, http://dx.doi.org/10.1111/j.1755-6724.1991.mp4002001

Roger, F., Leloup, P. H., Jolivet, M., Lacassin, R., Trinh, P. T., Brunel, M., and Seward, D., 2000, Long and complex thermal history of the Song Chay metamorphic dome (Northern Vietnam) by multi-system geochronology: Tectonophysics, v. 321, n. 4, p. 449-466, http://dx.doi.org/10.1016/S0040$1951(00) 00085-8$

Roger, F., Maluski, H., Leyreloup, A., Lepvrier, C., and Thi, P. T., 2007, U-Pb dating of high temperature metamorphic episodes in the Kon Tum Massif (Vietnam): Journal of Asian Earth Sciences, v. 30, n. 3-4, p. 565-572, http://dx.doi.org/10.1016/j.jseaes.2007.01.005

Sandiford, M., and Hand, M., 1998, Controls on the locus of intraplate deformation in central Australia: Earth and Planetary Science Letters, v. 162, n. 1-4, p. 97-110, http://dx.doi.org/10.1016/S0012821X (98) 00159-9

Sandiford, M., and McLaren, S., 2002, Tectonic feedback and the ordering of heat producing elements within the continental lithosphere: Earth and Planetary Science Letters, v. 204, n. 1-2, p. 133-150, http:/ /dx.doi.org/10.1016/S0012-821X(02)00958-5

Sandiford, M., Hand, M., and McLaren, S., 2001, Tectonic feedback, intraplate orogeny and the geochemical structure of the crust: A central Australian perspective, in Miller, J. A., Holdsworth, R. E., Buick, I. S. and Hand, M., editors, Continental Reactivation and Reworking: Geological Society, London, Special Publications, v. 184, p. 195-218, http://dx.doi.org/10.1144/GSL.SP.2001.184.01.10

Sandiford, M., McLaren, S., and Neumann, N., 2002, Long-term thermal consequences of the redistribution of heat-producing elements associated with large-scale granitic complexes: Journal of Metamorphic Geology, v. 20, n. 1, p. 87-98, http://dx.doi.org/10.1046/j.0263-4929.2001.00359.x

Sandiford, M., Wallace, M., and Coblentz, D., 2004, Origin of the in-situ stress field in southeastern Australia: Basin Research, v. 16, n. 3, p. 325-338, http://dx.doi.org/10.1111/j.1365-2117.2004.00235.x

Scrimgeour, I., and Raith, J. G., 2001, High-grade reworking of Proterozoic granulites during Ordovician intraplate transpression, eastern Arunta Inlier, central Australia: Geological Society, London, Special Publications, v. 184, p. 261-287, http://dx.doi.org/10.1144/GSL.SP.2001.184.01.13

Shu, L. S., Lu, H. F., Jia, D., Charvet, J., and Faure, M., 1999, Study of the ${ }^{40} \mathrm{Ar} /{ }^{39} \mathrm{Ar}$ isotopic age for the early Paleozoic tectonothermal event in the Wuyishan region, South China: Journal of Nanjing University (Natural Sciences), v. 35, n. 6, p. 668-674 (in Chinese with English abstract).

Shu, L. S., Yu, J. H., Jia, D., Wang, B., Shen, W. Z., and Zhang, Y. Q., 2008, Early Paleozoic orogenic belt in the eastern segment of South China: Geological Bulletin of China, v. 27, n. 10, p. 1581-1593 (in Chinese with English abstract).

Shu, L. S., Faure, M., Yu, J. H., and Jahn, B. M., 2011, Geochronological and geochemical features of the Cathaysia block (South China): New evidence for the Neoproterozoic breakup of Rodinia: Precambrian Research, v. 187, n. 3-4, p. 263-276, http://dx.doi.org/10.1016/j.precamres.2011.03.003

Shu, L. S., Jahn, B. M., Charvet, J., Santosh, M., Wang, B., Xu, X. S., and Jiang, S. Y., 2014, Early Paleozoic depositional environment and intraplate tectono-magmatism in the Cathaysia Block (South China): Evidence from stratigraphic, structural, geochemical and geochronological investigations: American Journal of Science, v. 314, n. 1, p. 154-186, http://dx.doi.org/10.2475/01.2014.05

Song, S. G., Ji, J. Q., Wei, C. J., Su, L., Zheng, Y. D., Song, B., and Zhang, L. F., 2007, Early Paleozoic granite in Nujiang River of northwest Yunnan in southwestern China and its tectonic implications: Chinese Science Bulletin, v. 52, n. 17. p. 2402-2406, http://dx.doi.org/10.1007/s11434-007-0301-2

Squire, R. J., Campbell, I. H., Allen, C. M., and Wilson, C. J. L., 2006, Did the Transgondwanan Supermountain trigger the explosive radiation of animals on Earth?: Earth and Planetary Science Letters, v. 250, n. 1-2, p. 116-133, http://dx.doi.org/10.1016/j.epsl.2006.07.032

Stewart, M., Holdsworth, R. E., and Strachan, R. A., 2000, Deformation processes and weakening mechanisms within the frictional-viscous transition zone of major crustal-scale faults: Insights from the Great Glen Fault Zone, Scotland: Journal of Structural Geology, v. 22, n. 5, p. 543-560, http://dx.doi.org/ 10.1016/S0191-8141(99)00164-9

Ting, V. K., 1929, The orogenic movement in China: Bulletin of the Geological Society of China, v. 8, n. 2, p. 151-170, http://dx.doi.org/10.1111/j.1755-6724.1929.mp8002007

Tommasi, A., and Vauchez, A., 1997, Continental-scale rheological heterogeneities and complex intraplate tectono-metamorphic patterns: Insights from a case-study and numerical models: Tectonophysics, v. 279, n. 1-4, p. 327-350, http://dx.doi.org/10.1016/S0040-1951(97)00117-0

Torsvik, T. H., and Cocks, L. R. M., 2009, The Lower Palaeozoic palaeogeographical evolution of the northeastern and eastern peri-Gondwanan margin from Turkey to New Zealand: Geological Society, London, Special Publications, v. 325, p. 3-21, http://dx.doi.org/10.1144/SP325.2

Torsvik, T. H., Carter, L. M., Ashwal, L. D., Bhushan, S. K., Pandit, M. K., and Jamtveit, B., 2001, Rodinia refined or obscured: Palaeomagnetism of the Malani igneous suite (NW India): Precambrian Research, v. 108, n. 3-4, p. 319-333, http://dx.doi.org/10.1016/S0301-9268(01)00139-5

Usuki, T., Lan, C. Y., Yui, T. F., Iizuka, Y., Vu, T. V., Tran, T. A., Okamoto, K., Wooden, J. L., and Liou, J. G., 2009, Early Paleozoic medium-pressure metamorphism in central Vietnam: evidence from SHRIMP $\mathrm{U}-\mathrm{Pb}$ zircon ages: Geosciences Journal, v. 13, p. 245-256, http://dx.doi.org/10.1007/s12303-0090024-2

Vilà, M., Fernández, M., and Jiménez-Munt, I., 2010, Radiogenic heat production variability of some 
common lithological groups and its significance to lithospheric thermal modeling: Tectonophysics, v. 490, n. 3-4, p. 152-164, http://dx.doi.org/10.1016/j.tecto.2010.05.003

Walker, J. D., Geissman, J. W., Bowring, S. A., and Babcock, L. E., 2013, The Geological Society of America Geologic Time Scale: Geological Society of America Bulletin, v. 125, n. 3-4, p. 259-272, http:// dx.doi.org/10.1130/B30712.1

Wan, Y. S., Liu, D. Y., Xu, M. H., Zhuang, J., Song, B., Shi, Y., and Du, L., 2007, SHRIMP U-Pb zircon geochronology and geochemistry of metavolcanic and metasedimentary rocks in Northwestern Fujian, Cathaysia Block, China: Tectonic implications and the need to redefine lithostratigraphic units: Gondwana Research, v. 12, n. 1-2, p. 166-183, http://dx.doi.org/10.1016/j.gr.2006.10.016

Wan, Y. S., Liu, D. Y., Wilde, S. A., Cao, J. J., Chen, B., Dong, C. Y., Song, B., and Du, L. L., 2010, Evolution of the Yunkai Terrane, South China: Evidence from SHRIMP zircon U-Pb dating, geochemistry and $\mathrm{Nd}$ isotope: Journal of Asian Earth Sciences, v. 37, n. 2, p. 140-153, http://dx.doi.org/10.1016/ j.jseaes.2009.08.002

Wang, D., Zheng, J., Ma, Q., Griffin, W. L., Zhao, H., and Wong, J., 2013a, Early Paleozoic crustal anatexis in the intraplate Wuyi-Yunkai orogen, South China: Lithos, v. 175-176, p. 124-145, http://dx.doi.org/ 10.1016/j.lithos.2013.04.024

Wang, J., and Li, Z. X., 2003, History of Neoproterozoic rift basins in South China: Implications for Rodinia break-up: Precambrian Research, v. 122, n. 1-4, p. 141-158, http://dx.doi.org/10.1016/S03019268(02) 00209-7

Wang, J. Q., Shu, L. S., Santosh, M., and Xu, Z. Q., 2014a, The Pre-Mesozoic crustal evolution of the Cathaysia Block, South China: Insights from geological investigation, zircon U-Pb geochronology, Hf isotope and REE geochemistry from the Wugongshan complex: Gondwana Research, v. 28, n. 1, p. 225-245, http://dx.doi.org/10.1016/j.gr.2014.03.008

Wang, L., Long, W. G., and Zhou, D., 2013b, Zircon LA-ICP-MS U-Pb age of Caledonian granites from Precambrian basement in Yunkai area and its geological implications: Geology in China, v. 40, n. 4, p. 1016-1029 (in Chinese with English abstract).

Wang, X. C., Li, Z. X., Li, X. H., Li, Q. L., and Zhang, Q. R., 2011a, Geochemical and Hf-Nd isotope data of Nanhua rift sedimentary and volcaniclastic rocks indicate a Neoproterozoic continental flood basalt provenance: Lithos, v. 127, n. 3-4, p. 427-440, http://dx.doi.org/10.1016/j.lithos.2011.09.020

Wang, X. X., Zhang, J. J., Santosh, M., Liu, J., Yan, S., and Guo, L., 2012a, Andean-type orogeny in the Himalayas of south Tibet: Implications for early Paleozoic tectonics along the Indian margin of Gondwana: Lithos, v. 154, p. 248-262, http://dx.doi.org/10.1016/j.lithos.2012.07.011

Wang, Y., Long, L., Wang, D. H., Zhang, C. Q., Hou, K. J., and Wang, C. H., 2011b, LA-ICP-MS Zircon U-Pb Dating of the Qinjia Granite in Guangxi Province and its geological significance: Acta Geologica Sinica, v. 85, n. 4 , p. $475-481$.

Wang, Y. J., Fan, W. M., Zhao, G. C., Ji, S. C., and Peng, T. P., 2007, Zircon U-Pb geochronology of gneissic rocks in the Yunkai massif and its implications on the Caledonian event in the South China Block: Gondwana Research, v. 12, n. 4, p. 404-416, http://dx.doi.org/10.1016/j.gr.2006.10.003

Wang, Y. J., Zhang, F. F., Fan, W., Zhang, G., Chen, S., Cawood, P. A., and Zhang, A., 2010, Tectonic setting of the South China Block in the early Paleozoic: Resolving intracontinental and ocean closure models from detrital zircon U-Pb geochronology: Tectonics, v. 29, n. 6, p. TC6020, http://dx.doi.org/10.1029/ 2010TC002750

Wang, Y. J., Zhang, A. M., Fan, W. M., Zhao, G. C., Zhang, G. W., Zhang, Y. Z., Zhang, F. F., and Li, S. Z., 2011c, Kwangsian crustal anatexis within the eastern South China Block: Geochemical, zircon U-Pb geochronological and Hf isotopic fingerprints from the gneissoid granites of Wugong and Wuyi-Yunkai Domains: Lithos, v. 127, n. 1-2, p. 239-260, http://dx.doi.org/10.1016/j.lithos.2011.07.027

Wang, Y.J., Wu, C. M., Zhang, A. M., Fan, W. M., Zhang, Y. H., Zhang, Y. Z., Peng, T. P., and Yin, C. Q., 2012b, Kwangsian and Indosinian reworking of the eastern South China Block: Constraints on zircon U-Pb geochronology and metamorphism of amphibolites and granulites: Lithos, v. 150, p. 227-242, http:// dx.doi.org/10.1016/j.lithos.2012.04.022

Wang, Y. J., Zhang, A., Fan, W., Zhang, Y., and Zhang, Y., 2013c, Origin of paleosubduction-modified mantle for Silurian gabbro in the Cathaysia Block: Geochronological and geochemical evidence: Lithos, v. 160-161, p. 37-54, http://dx.doi.org/10.1016/j.lithos.2012.11.004

Wang, Y. J., Xing, X. W., Cawood, P. A., Lai, S. C., Xia, X. P., Fan, W. M., Liu, H. C., and Zhang, F. F., 2013d, Petrogenesis of early Paleozoic peraluminous granite in the Sibumasu Block of SW Yunnan and diachronous accretionary orogenesis along the northern margin of Gondwana: Lithos, v. 182-183, p. 67-85, http://dx.doi.org/10.1016/j.lithos.2013.09.010

Wang, Y. J., Zhang, A. M., Cawood, P. A., Zhang, Y. Z., Fan, W. M., and Zhang, G. W., 2013e, Geochronological, geochemical and Nd-Hf-Os isotopic fingerprinting of an early Neoproterozoic arc-back-arc system in South China and its accretionary assembly along the margin of Rodinia: Precambrian Research, v. 231, p. 343-371, http://dx.doi.org/10.1016/j.precamres.2013.03.020

Wang, Y. J., Zhang, Y., Fan, W., Geng, H., Zou, H., and Bi, X., 2014b, Early Neoproterozoic accretionary assemblage in the Cathaysia Block: Geochronological, $\mathrm{Lu}-\mathrm{Hf}$ isotopic and geochemical evidence from granitoid gneisses: Precambrian Research, v. 249, p. 144-161, http://dx.doi.org/10.1016/j. precamres.2014.05.003

Wannamaker, P. E., Caldwell, T. G., Jiracek, G. R., Maris, V., Hill, G. J., Ogawa, Y., Bibby, H. M., Bennie, S. L., and Heise, W., 2009, Fluid and deformation regime of an advancing subduction system at Marlborough, New Zealand: Nature, v. 460, n. 7256, p. 733-736, http://dx.doi.org/10.1038/nature08204

Wu, Y. B., Hanchar, J. M., Gao, S., Sylvester, P. J., Tubrett, M., Qiu, H. N., Wijbrans, J. R., Brouwer, F. M., Yang, S. H., Yang, Q. J., Liu, Y. S., and Yuan, H. L., 2009, Age and nature of eclogites in the Huwan shear zone, and the multi-stage evolution of the Qinling-Dabie-Sulu orogen, central China: Earth and Planetary Science Letters, v. 277, n. 3-4, p. 345-354, http://dx.doi.org/10.1016/j.epsl.2008.10.031 
Xia, Y., Xu, X., Zou, H., and Liu, L., 2014, Early Paleozoic crust-mantle interaction and lithosphere delamination in South China Block: Evidence from geochronology, geochemistry, and Sr-Nd-Hf isotopes of granites: Lithos, v. 184-187, p. 416-435, http://dx.doi.org/10.1016/j.lithos.2013.11.014

Xiang, L., and Shu, L. S., 2010, Pre-Devonian tectonic evolution of the eastern South China Block: Geochronological evidence from detrital zircons: Science China Earth Sciences, v. 53, n. 10, p. 14271444, http://dx.doi.org/10.1007/s11430-010-4061-5

Xu, D. R., Xia, B., Li, P. C., Chen, G. H., Ma, C., and Zhang, Y. Q., 2007, Protolith natures and U-Pb sensitive high mass-resolution ion microprobe (SHRIMP) zircon ages of the metabasites in Hainan Island, South China: Implications for geodynamic evolution since the late Precambrian: Island Arc, v. 16, n. 4, p. 575-597, http://dx.doi.org/10.1111/j.1440-1738.2007.00584.x

Xu, D. R., Xia, B., Bakun-Czubarow, N., Bachlinski, R., Li, P., and Chen, T., 2008, Geochemistry and Sr-Nd isotope systematics of metabasites in the Tunchang area, Hainan Island, South China: Implications for petrogenesis and tectonic setting: Mineralogy and Petrology, v. 92, n. 3, p. 361-391, http://dx.doi.org/ $10.1007 / \mathrm{s} 00710-007-0198-0$

Xu, X. B., Zhang, Y., Shu, L., Jia, D., Wang, R. R., and Xu, H. Z., 2009, Zircon La-ICPMS U-Pb dating of the Weipu granitic pluton in southwest Fujian and the Changpu migmatite in south Jiangxi: constrains to the timing of Caledonian movement in Wuyishan mountains: Geological Review, v. 55, n. 2, p. 277-285 (in Chinese with English abstract).

Xu, X. B., Zhang, Y. Q., Shu, L. S., and Jia, D., 2011, La-ICP-MS U-Pb and ${ }^{40} \mathrm{Ar} /{ }^{39} \mathrm{Ar}$ geochronology of the sheared metamorphic rocks in the Wuyishan: Constraints on the timing of Early Paleozoic and Early Mesozoic tectono-thermal events in SE China: Tectonophysics, v. 501, n. 1-4, p. 71-86, http:// dx.doi.org/10.1016/j.tecto.2011.01.014

Xu, Y. J., Du, Y. S., Cawood, P. A., Zhu, Y. H., Li, W. C., and Yu, W. C., 2012, Detrital zircon provenance of Upper Ordovician and Silurian strata in the northeastern Yangtze Block: Response to orogenesis in South China: Sedimentary Geology, v. 267-268, p. 63-72, http://dx.doi.org/10.1016/j. sedgeo.2012.05.009

Xu, Y. J., Cawood, P. A., Du, Y. S., Hu, L. S., Yu, W. C., Zhu, Y. H., and Li, W. C., 2013, Linking South China to northern Australia and India on the margin of Gondwana: Constraints from detrital zircon U-Pb and $\mathrm{Hf}$ isotopes in Cambrian strata: Tectonics, v. 32, n. 6, p. 1547-1558, http://dx.doi.org/10.1002/tect.20099

Xu, Y. J., Cawood, P. A., Du, Y. S., Huang, H. W., and Wang, X. Y., 2014a, Early Paleozoic orogenesis along Gondwana's northern margin constrained by provenance data from South China: Tectonophysics, v. 636 , p. 40-51, http://dx.doi.org/10.1016/j.tecto.2014.08.022

Xu, Y. J., Cawood, P. A., Du, Y. S., Zhong, Z. Q., and Hughes, N. C., 2014b, Terminal suturing of Gondwana along the southern margin of South China Craton: Evidence from detrital zircon U-Pb ages and Hf isotopes in Cambrian and Ordovician strata, Hainan Island: Tectonics, v. 33, n. 12, p. 2490-2504, http://dx.doi.org/10.1002/2014TC003748

Yang, D. S., Li, X. H., Li, W. X., Liang, X. Q., Long, W. G., and Xiong, X. L., 2010, U-Pb and ${ }^{40} \mathrm{Ar}-{ }^{39} \mathrm{Ar}$ geochronology of the Baiyunshan gneiss (central Guangdong, south China): Constraints on the timing of early Palaeozoic and Mesozoic tectonothermal events in the Wuyun (Wuyi-Yunkai) Orogen: Geological Magazine, v. 147, n. 4, p. 481-496, http://dx.doi.org/10.1017/S0016756809990811

Yang, Y., and Liu, M., 2009, Crustal thickening and lateral extrusion during the Indo-Asian collision: A 3D viscous flow model: Tectonophysics, v. 465, n. 1-4, p. 128-135, http://dx.doi.org/10.1016/ j.tecto.2008.11.002

Yang, Z., Sun, Z., Yang, T., and Pei, J., 2004, A long connection (750-380 Ma) between South China and Australia: Paleomagnetic constraints: Earth and Planetary Science Letters, v. 220, n. 3-4, p. 423-434, http://dx.doi.org/10.1016/S0012-821X(04)00053-6

Yang, Z, Wang, R. C., Zhang., W. L., et al. 2014, Skarn-type tungsten mineralization associated with the Caledonian (Silurian) Niutangjie granite, northern Guangxi, China: Science China: Earth Sciences, v. 57, n. 7, p. 1551-1566, http://dx.doi.org/10.1007/s11430-014-4838-z

Yao, J., Shu, L., and Santosh, M., 2011, Detrital zircon U-Pb geochronology, Hf-isotopes and geochemistryNew clues for the Precambrian crustal evolution of Cathaysia Block, South China: Gondwana Research, v. 20, n. 2-3, p. 553-567, http://dx.doi.org/10.1016/j.gr.2011.01.005

Yao, W. H., Li, Z. X., Li, W. X., Wang, X. C., Li, X. H., and Yang, J. H., 2012, Post-kinematic lithospheric delamination of the Wuyi-Yunkai orogen in South China: Evidence from ca. $435 \mathrm{Ma}$ high-Mg basalts: Lithos, v. 154, p. 115-129, http://dx.doi.org/10.1016/j.lithos.2012.06.033

Yao, W. H., Li, Z. X., Li, W. X., and Yang, J. H., 2014a, From Rodinia to Gondwanaland: A tale of detrital zircon provenance analyses from the southern Nanhua Basin, South China: American Journal of Science, v. 314, n. 1, p. 278-313, http://dx.doi.org/10.2475/01.2014.08

Yao, W. H., Li, Z. X., Li, W. X., Su, L., and Yang, J. H., 2014b, Detrital provenance evolution of the Ediacaran-Silurian Nanhua foreland basin, South China: Gondwana Research, v. 28, n. 4, p. 1449 1465, http://dx.doi.org/10.1016/j.gr.2014.10.018

Yardley, B. W. D., 2009, The role of water in the evolution of the continental crust: Journal of the Geological Society, v. 166, n. 4, p. 585-600, http://dx.doi.org/10.1144/0016-76492008-101

Yin, A., 2010, Cenozoic tectonic evolution of Asia: A preliminary synthesis: Tectonophysics, v. 488, n. 1-4, p. 293-325, http://dx.doi.org/10.1016/j.tecto.2009.06.002

Yin, A., Dubey, C. S., Kelty, T. K., Webb, A. A. G., Harrison, T. M., Chou, C. Y., and Célérier, J., 2010, Geologic correlation of the Himalayan orogen and Indian craton: Part 2. Structural geology, geochronology, and tectonic evolution of the Eastern Himalaya: Geological Society of America Bulletin, v. 122, n. 3-4, p. 360-395, http://dx.doi.org/10.1130/B26461.1

Yu, J. H., Zhou, X., O'Reilly, S. Y., Zhao, L., Griffin, W. L., Wang, R., Wang, L., and Chen, X., 2005, Formation history and protolith characteristics of granulite facies metamorphic rock in Central Cathaysia deduced 
from $\mathrm{U}-\mathrm{Pb}$ and $\mathrm{Lu}-\mathrm{Hf}$ isotopic studies of single zircon grains: Chinese Science Bulletin, v. 50, n. 18, p. 2080-2089, http://dx.doi.org/10.1360/982004-808

Yu, J. H., O’Reilly, S. Y., Wang, L. J., Griffin, W. L., Zhang, M., Wang, R. C., Jiang, S. Y., and Shu, L. S., 2008, Where was South China in the Rodinia supercontinent? Evidence from U-Pb geochronology and $\mathrm{Hf}$ isotopes of detrital zircons: Precambrian Research, v. 164, n. 1-2, p. 1-15, http://dx.doi.org/10.1016/ j.precamres.2008.03.002

Yu, J. H., Lou, F. S., Wang, L. J., Shen, L. W., Zhou, X. Y., Zhang, C. H., and Huang, Z. Z., 2014a, The geological significance of a Paleozoic mafic granulite found in the Yiyang area of northeastern Jiangxi Province (in Chinese): Chinese Science Bulletin (Chinese Version), v. 59, n. 35, p. 3508-3516, doi: http://dx.doi.org/10.1360/N972014-00395

Yu, W., Du, Y., Cawood, P. A., Xu, Y. J., and Yang, J. H., 2014b, Detrital zircon evidence for the reactivation of an Early Paleozoic syn-orogenic basin along the North Gondwana margin in South China: Gondwana Research, v. 28, n. 2, p. 769-780, http://dx.doi.org/10.1016/j.gr.2014.07.014

Zeng, W., Zhang, L., Zhou, H. W., Zhong, Z. Q., Xiang, H., Liu, R., Jin, S., Lü, X. Q., and Li, C. Z., 2008, Caledonian reworking of Paleoproterozoic basement in the Cathaysia Block: Constraints from zircon $\mathrm{U}-\mathrm{Pb}$ dating, Hf isotopes and trace elements: Chinese Science Bulletin, v. 53, n. 6, p. 895-904, http:/ /dx.doi.org/10.1007/s11434-008-0076-0

Zhang, A. M., Wang, Y. J., Fan, W. M., Zhang, F. F., and Zhang, Y. Z., 2010a, LA-ICPMS Zircon U-Pb Geochronology and Hf Isotopic Compositions of Caledonian Granites From the Qingliu Area, Southwest Fujian: Geotectonica et Metallogenia, v. 34, n. 3, p. 408-418 (in Chinese with English abstract).

Zhang, A. M., Wang, Y. J., Fan, W. M., Zhang, F. F., and Zhang, Y. Z., 2011a, LA-ICPMS Zircon U-Pb Geochronology and Hf Isotopic Composition of the Taoxi Migmatite (Wuping): Constrains on the Formation Age of the Taoxi Complex and the Yunanian Event: Geotectonica et Metallogenia, v. 35, n. 1, p. 64-72 (in Chinese with English abstract).

Zhang, F. F., Wang, Y. J., Fan, W. M., Zhang, A. M., and Zhang, Y. Z., 2010b, LA-ICPMS zircon U-Pb geochronology of late Early Paleozoic granites in eastern Hunan and western Jiangxi provinces, South China: GEOCHIMICA, v. 39, n. 5, p. 414-426 (in Chinese with English abstract).

Zhang, F. F., Wang, Y. J., Zhang, A. M., Fan, W. M., Zhang, Y. Z., and Zi, J. W., 2012a, Geochronological and geochemical constraints on the petrogenesis of Middle Paleozoic (Kwangsian) massive granites in the eastern South China Block: Lithos, v. 150, p. 188-208, http://dx.doi.org/10.1016/j.lithos.2012.03.011

Zhang, Q. R., Li, X. H., Feng, L. J., Huang, J., and Song, B., 2008, A New Age Constraint on the Onset of the Neoproterozoic Glaciations in the Yangtze Platform, South China: The Journal of Geology, v. 116, n. 4, p. 423-429, http://dx.doi.org/10.1086/589312

Zhang, S. H., Evans, D. A. D., Li, H., Wu, H., Jiang, G., Dong, J., Zhao, Q., Raub, T. D., and Yang, T., 2013a, Paleomagnetism of the late Cryogenian Nantuo Formation and paleogeographic implications for the South China Block: Journal of Asian Earth Sciences, v. 72, p. 164-177, http://dx.doi.org/10.1016/ j.jseaes.2012.11.022

Zhang, W. L., Wang, R. C., Lei, Z. H., Hua, R. M., Zhu, J. C., Lu, J. J., Xie, L., Che, X. D., Zhang, R. Q., Yao, Y., and Chen, J., 2011b, Zircon U-Pb dating confirms existence of a Caledonian scheelite-bearing aplitic vein in the Penggongmiao granite batholith, South Hunan: Chinese Science Bulletin, v. 56, n. 19, p. 2031-2036, http://dx.doi.org/10.1007/s11434-011-4526-8

Zhang, Y., Shu, L. S., and Chen, X. Y., 2011c, Geochemistry, geochronology, and petro-genesis of the early Paleozoic granitic plutons in the central-southern Jiangxi Province, China: Science China Earth Sciences, v. 54, n. 10, p. 1492-1510, http://dx.doi.org/10.1007/s11430-011-4249-3

Zhang, Z. J., Xu, T., Zhao, B., and Badal, J., 2013b, Systematic variations in seismic velocity and reflection in the crust of Cathaysia: New constraints on intraplate orogeny in the South China continent: Gondwana Research, v. 24, n. 3-4, p. 902-917, http://dx.doi.org/10.1016/j.gr.2012.05.018

Zhang, Z. M., Wang, L. J., Shen, K., and Shi, C., 2008, Paleozoic circum-Gondwana orogens: Petrology and geochemistry of the Namche Barwa Complex in the eastern Himalaya syntaxis, Tibet: Acta Petrologica Sinica, v. 24, n. 7, p. 1627-1637 (in Chinese with English abstract).

Zhang, Z. M., Dong, X., Santosh, M., Liu, F., Wang, W., Yiu, F., He, Z., and Shen, K., 2012b, Petrology and geochronology of the Namche Barwa Complex in the eastern Himalayan syntaxis, Tibet: Constraints on the origin and evolution of the north-eastern margin of the Indian Craton: Gondwana Research, v. 21, n. 1, p. 123-137, http://dx.doi.org/10.1016/j.gr.2011.02.002

Zhao, G. C., and Cawood, P. A., 1999, Tectonothermal evolution of the Mayuan assemblage in the Cathaysia Block: Implications for Neoproterozoic collisional-related assembly of the South China craton: American Journal of Science, v. 299, n. 4, p. 309-339, http://dx.doi.org/10.2475/ajs.299.4.309

2012, Precambrian geology of China: Precambrian Research, v. 222-223, p. 13-54, http://dx.doi.org/ 10.1016/j.precamres.2012.09.017

Zhao, J. H., and Asimow, P. D., 2014, Neoproterozoic boninite-series rocks in China: A depleted mantle source modified by sediment-derived melt: Chemical Geology, v. 388, p. 98-111, http://dx.doi.org/ 10.1016/j.chemgeo.2014.09.004

Zhao, J. H., Zhou, M. F., Yan, D. P., Zheng, J. P., and Li, J. W., 2011, Reappraisal of the ages of Neoproterozoic strata in South China: No connection with the Grenvillian orogeny: Geology, v. 39, n. 4, p. 299-302, http://dx.doi.org/10.1130/G31701.1

Zhao, K., Jiang, S., Sun, T., Chen, W., Ling, H., and Chen, P., 2013, Zircon U-Pb dating, trace element and Sr-Nd-Hf isotope geochemistry of Paleozoic granites in the Miao'ershan-Yuechengling batholith, South China: Implication for petrogenesis and tectonic-magmatic Evolution: Journal of Asian Earth Sciences, v. 74, p. 244-264, http://dx.doi.org/10.1016/j.jseaes.2012.12.026

Zhao, P., Wang, J. Y., Wang, J. A., and Luo, D. G., 1995, Characteristics of heat production distribution in SE China: Acta Petrologica Sinica, v. 11, n. 3, p. 292-305.

Zhong, Y., Ma, C., Zhang, C., Wang, S., She, Z., Liu, L., and Xu, H., 2013, Zircon U-Pb age, Hf isotopic 
compositions and geochemistry of the Silurian Fengdingshan I-type granite Pluton and Taoyuan mafic-felsic Complex at the southeastern margin of the Yangtze Block: Journal of Asian Earth Sciences, v. 74, p. 11-24, http://dx.doi.org/10.1016/j.jseaes.2013.05.025

Zhong, Y., Ma, C., Liu, L., Zhao, J., Zheng, J., Nong, J., and Zhang, Z., 2014, Ordovician appinites in the Wugongshan Domain of the Cathaysia Block, South China: Geochronological and geochemical evidence for intrusion into a local extensional zone within an intracontinental regime: Lithos, v. 198-199, p. 202-216, http://dx.doi.org/10.1016/j.lithos.2014.04.002

Zhou, M. F., Yan, D. P., Kennedy, A. K., Li, Y. Q., and Ding, J., 2002, SHRIMP U-Pb zircon geochronological and geochemical evidence for Neoproterozoic arc magmatism along the western margin of the Yangtze Block, South China: Earth and Planetary Science Letters, v. 196, n. 1-2, p. 51-67, http://dx.doi.org/ 10.1016/S0012-821X(01)00595-7

Ziegler, P. A., Cloetingh, S., and van Wees, J. D., 1995, Dynamics of intra-plate compressional deformation: The Alpine foreland and other examples: Tectonophysics, v. 252, n. 1-4, p. 7-59, http://dx.doi.org/ $10.1016 / 0040-1951(95) 00102-6$ 